\title{
ENVIRONMENTAL DISTURBANCE TRIGGERING INFESTATIONS OF GORSE, RABBITS, AND THISTLES IN SOUTHERN NEW ZEALAND: 1850 TO 1980
}

PETER HOLLAND' AND GUIL FIGGINS²

Department of Geography

University of Otago

PO Box 56, Dunedin

\section{Abstract}

In the first four decades of organised European settlement in southern New Zealand, gorse was planted in straight lines on farms and stations for hedges and shelter, rabbits were released at localities around the coast and in the interior for recreation and the pot, and thistle seeds were inadvertently carried to properties as pollutants in sacks of imported grass seed and the fleeces of sheep. Within a decade of becoming established on a property, each became a nuisance. Entries in farm and station letter books and diaries, ledgers and cash books, the minute books of local and national government agencies, and reports to parliament enabled us to characterise the dispersal routes and refuges of rabbits in the former tussock grass and low shrub country of southern New Zealand, and to investigate the nature, cost and effectiveness of control measures employed by land holders, local bodies and the state. We suggest that ecological theory, with its emphasis on interactions and interconnections between living things and their environments, can deepen our understanding of the spread, establishment, and dominance of these three introduced organisms after episodes of environmental disturbance, natural as well as artificial, have created opportunities for them to thrive.

Keywords: environmental disturbance, gorse, rabbits, thistles, ecological opportunities, habitats of disturbance, refuge areas, pest control and eradication, farms as ecological systems, ecological succession.

$1 \quad$ Corresponding author: Peter Holland: pgh@geography.otago.ac.nz.

2 Peter Holland is Emeritus Professor in Geography at the University of Otago. Guil Figgins recently graduated $\mathrm{PhD}$ in Geography at the University of Otago. 


\section{Introduction}

Through their efforts to burn or uproot native plants, drain wetlands and plough the topsoil, did European settlers in southern New Zealand inadvertently trigger ecological processes that would facilitate the spontaneous spread, establishment, and dominance of introduced species such as gorse, thistles, and rabbits? Entries in European settlers' diaries and letter books, local and national government reports, and the records of land companies suggest that this was the case, and we have evaluated the evidence in the light of ecological theory.

In southern New Zealand, extensive tussock grass and low shrublands with stands of trees in gullies and moist ground (hereafter termed 'the open country') (Map 1), were known to the indigenous Māori (tangata whenua or iwi), who had fostered the development and persistence of this vegetation type by burning. The open country was dotted with places where such valued resources as plant and animal foods, scents and dyes were collected, criss-crossed by paths, and filled with meaning for iwi, who passed on their knowledge of it to succeeding generations. ${ }^{3}$ As organised European settlement got under way, surveyors mapped what they believed would be helpful to settlers: notably, coastlines, rivers and streams, water bodies and wetlands, well-used tracks, topographical features, and areas of wooded land. ${ }^{4}$ With the progression of European settlement, the communal landscapes of iwi were erased and in their place geometrical mosaics of large and small properties, each occupied by a family and regulated by the laws of the day, were established. Surveyors laid out grids of roads and section boundaries, imposed straight lines and obtuse angles on the landscape, delimited reserves for roads and tracks, and stored the details in land registers $^{5}$ that recorded an individual's right to occupy a property. In essence these early surveys were forward-looking, and an expression of society's vision for the new land as well as how it would be occupied. Aside from Māori place names current in the 1840 s and '50s, there were few mementoes on early maps of the prior landscape, iwi or their images of the land and, as George Griffiths has shown, several recorded Māori place names were spurious. ${ }^{6}$

\footnotetext{
3 M. J. Stevens, 'Ngāi Tahu and the 'nature' of Māori modernity', in Eric Pawson and Tom Brooking, Making a New Land: Environmental Histories of New Zealand (Dunedin: Otago University Press, 2013), 293-309.

4 Eric Pawson and Peter Holland, 'Lowland Canterbury landscapes in the making', New Zealand Geographer 61 (2005): 167-75.

5 G. Byrnes, 'Surveying spaces: constructing the colonial landscape', in B. Dalley and B. Labrum, Fragments. New Zealand Social and Cultural History (Auckland: Auckland University Press, 2000), 54-75; G. Byrnes, Boundary Markers: Land Surveying and the Colonisation of New Zealand (Wellington: Bridget Williams Books, 2001).

6 G. J. Griffiths, The Spurious Māori Place Names of Southern New Zealand (Dunedin: Otago Heritage Books, 2002).
} 


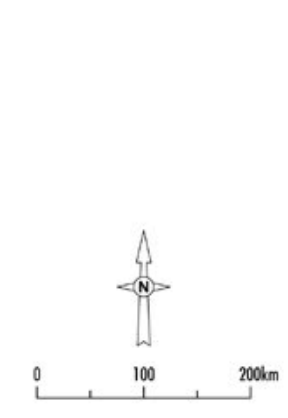

$\Upsilon^{2}$ The 'open country'
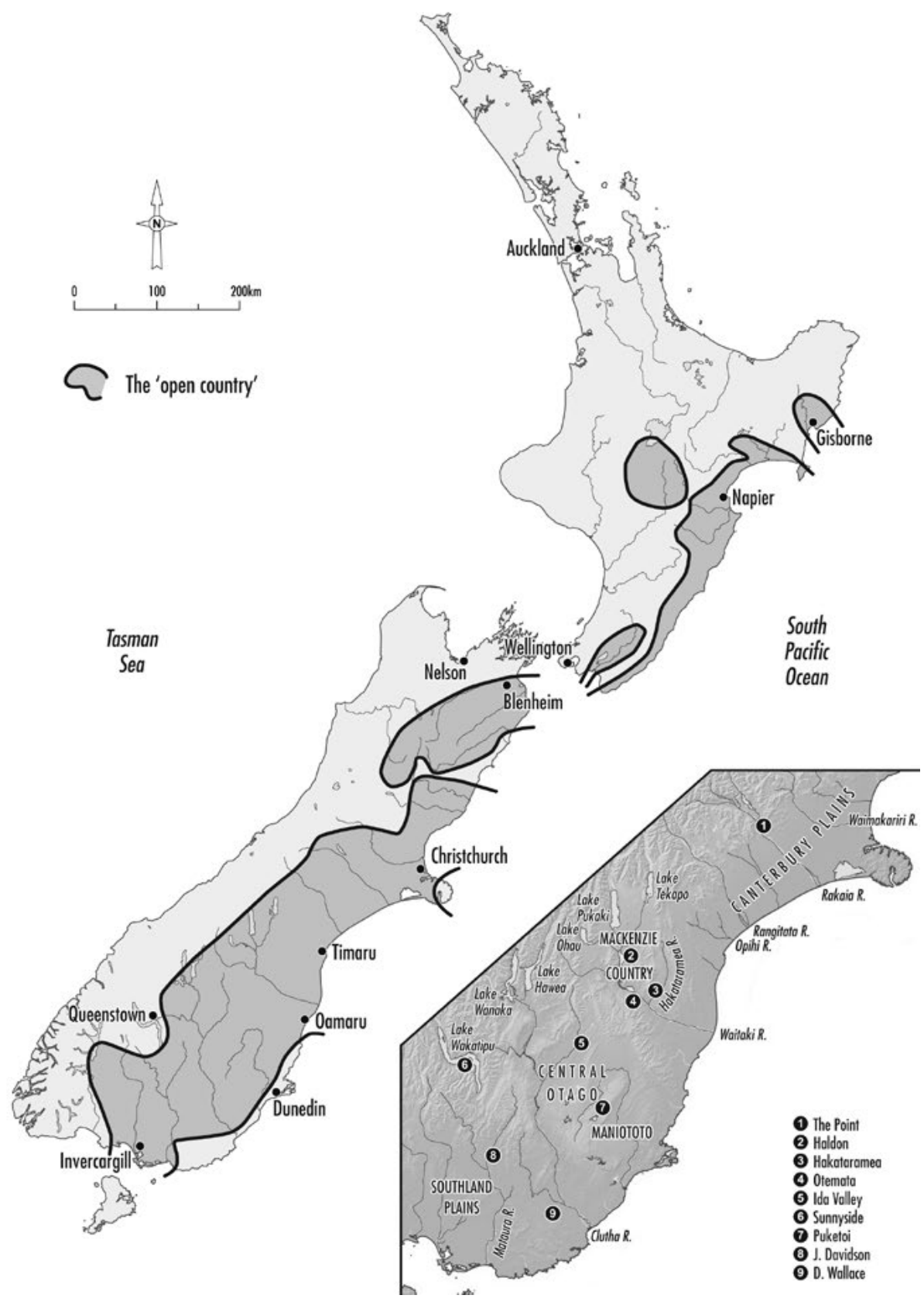

Map 1: The open country of southern New Zealand, showing the principal rivers, lakes, place names, and pioneer properties mentioned in the text.

Source: Redrawn from vegetation maps in I. Wards (ed.), New Zealand Atlas (Wellington, Government Printer, 1976). 
Compared with forested areas in the North Island, the open country of southern New Zealand was readily transformed into productive farms and sheep stations. Rural settlers based the economies of their properties on fine wool produced for the British market, and subsequent decisions about land use and landscape fell into place like checkers on a board. Several were to have significant environmental consequences for southern New Zealand, but few European settlers were alert to the ill effects in prospect. In his old age, Alexander Beange ruefully recalled his first year at Mimihau, five kilometres east of Wyndham in the Mataura valley, Southland, where he had pioneered a 500-acre block: 'The whole area was covered with tussock, and there was not a gorse bush or a rabbit to be seen ... in twelve years the settlers gradually brought the land under cultivation. ${ }^{7}$ Until the 1860s, as Beange and other European settlers discovered, the open country of southern New Zealand was the kingdom of grass, dominated by perennial native grasses and broad-leafed herbs, with occasional trees, shrubs, and bracken fern (Pteridium esculentum) in damp ground. Across the area, settlers found logs and tree stumps in moist places, remnants of fire several centuries before, which they used for pit props as well as for fuel, fence-posts and construction. ${ }^{8}$

Through newspapers and magazines, settlers had access to practical advice as well as commercial sources of the materials and tools they needed to transform their lowland properties into productive pastures and crop-land. The first generation believed that environmental transformation would catalyse economic improvement and result in more palatable herbage for sheep and cattle, fewer places where livestock would come to harm, and more efficient management. In this regard, we follow James Beattie and John Stenhouse in asking if the first generation of European settlers also recognised their parallel roles of stewards and transformers of the environment, and if these ideals were put into practice. ${ }^{9}$

Within a few years of settlement, the boundaries of a farm or lowland station had been wholly or partly delineated with hedges and fences to keep the family's livestock in and their neighbours' animals out. A property was split into blocks for the homestead and out-buildings, fields for crops, paddocks for sown pasture, and larger areas for extensive grazing, each bounded by hedges or fences. Land holders gave informal names to individual fields and paddocks to facilitate management, found that groves of cabbage trees (Cordyline australis) indicated damp ground, and learned to avoid tracts of soil too thin or stony to cultivate. The surveyor, Frederick Tuckett, as well as other early residents

$7 \quad$ Southland Times, 26 January 1949.

8 M. S. McGlone and J. M. Wilmshurst, 'Dating initial Maori environmental impact in New Zealand', Quaternary International 59 (1999): 5-16; B. P. J. Molloy, C. J. Burrows, J. E. Cox, J. A. Johnston, and P. Wardle, 'Distribution of sub-fossil forest remains, eastern South Island, New Zealand', New Zealand Journal of Botany 1 (1963): 68-77.

9 James Beattie and John Stenhouse, 'Empire, Environment and Religion: God and Nature in nineteenthcentury New Zealand', Environment and History 13 (2007): 413-46. 
wrote informative accounts for the guidance of intending settlers ${ }^{10}$ about the environmental diversity of southern New Zealand but, as Vaughan Wood has shown, not all early settlers were deluded by the 'biometric fallacy' that associated substantial biomass and rapid crop growth in newly cleared land as evidence for a nutrient-rich soil suited to agriculture in the long term. ${ }^{11}$

Gorse, rabbits, and thistles reached New Zealand from south-eastern Australia and the British Isles in the mid-nineteenth century. These three species have intertwined histories and exemplify the problems caused by many other introduced plant and animal species that became naturalised in New Zealand. This article is primarily concerned with the experiences of the first three generations of European settlers in the lowlands of southern New Zealand. At first, they held out high hopes for the first two species, but all three became serious nuisances. We suggest that the history, impact, and control of pest animals and noxious weeds are aspects of an ecological system that are usefully investigated holistically. We also show how ecological factors and forces relating to these undesirable newcomers were modulated by the social structures, environmental perceptions, and beliefs of settler society.

European settlers undertook widespread landscape change, normally with backing from private capital, and we ask (a) if individual human agency, being the actions of autonomous individuals who believe that change is possible, ${ }^{12}$ predominated in the early years of organised settlement, and (b) if collective human agency, which is 'expressed in the cultural, infrastructural and communications resources that enable collective action', ${ }^{13}$ became necessary later.

The agency of the non-human world was central to the difficulties faced by land holders in this period. The world of the rural settler was co-constituted by a wide range of human and non-human actors working upon each other to create networks and relationships that would shape a new and varied set of cultural and physical landscapes. On a settler's property, large flocks of sheep (Photo 1) and small herds of cattle were raised for meat and fibre, while bullocks and

\footnotetext{
10 Peter Holland, Kevin O'Connor, and Alexander Wearing, 'Remaking the grasslands of the open country', in Environmental Histories of New Zealand, ed. Eric Pawson and Tom Brooking (Melbourne: Oxford University Press, 2002), 69-83 \& 302-304.

11 Vaughan Wood, 'Appraising soil fertility in early colonial New Zealand: the 'biometric fallacy' and beyond', Environment and History 9 (2003): 393-405.

12 D. J. Davidson, 'The applicability of the concept of resilience to social systems: some sources of optimism and nagging doubts', Society and Natural Resources 23 (2010): 1135-49.

13 H. Lorimer, 'Human-Non-human', in P. Cloke, P. Crang, and M. Goodwin, Introducing Human Geographies (London: Hodder Arnold, 2005), 37-51; S. Whatmore, 'Dissecting the autonomous self: hybrid cartographies for a relationship ethics', Environment and Planning D: Society and Space 25 (1977): 37-53; R. Yarwood and N. Evans, 'Taking stock of farm animals and rurality', in C. Philo and C. Wilbert, Animal Geographies of Human-Animal Relations (London: Routledge, 2000), 98-114.
} 
horses were kept for transport and power, and dogs were valued as working animals. Over time, different relationships developed between the human and the non-human worlds through the medium of introduced plants and animals, and the new land was perceived by settlers as a blank canvas on which newcomers - people, plants and animals - would soon dominate. Relationships and processes that linked the human and non-human worlds were modified by social, economic, ecological, and technological changes, and the economy of a farm or station was both sustained and constrained by introduced plants and animals. This dynamic fostered new relationships between people and nature, as land holders learned to deal with environmental problems thrown up by the biophysical processes of native and introduced species, and as plants and animals exploited the ecological opportunities created by settlers. ${ }^{14}$

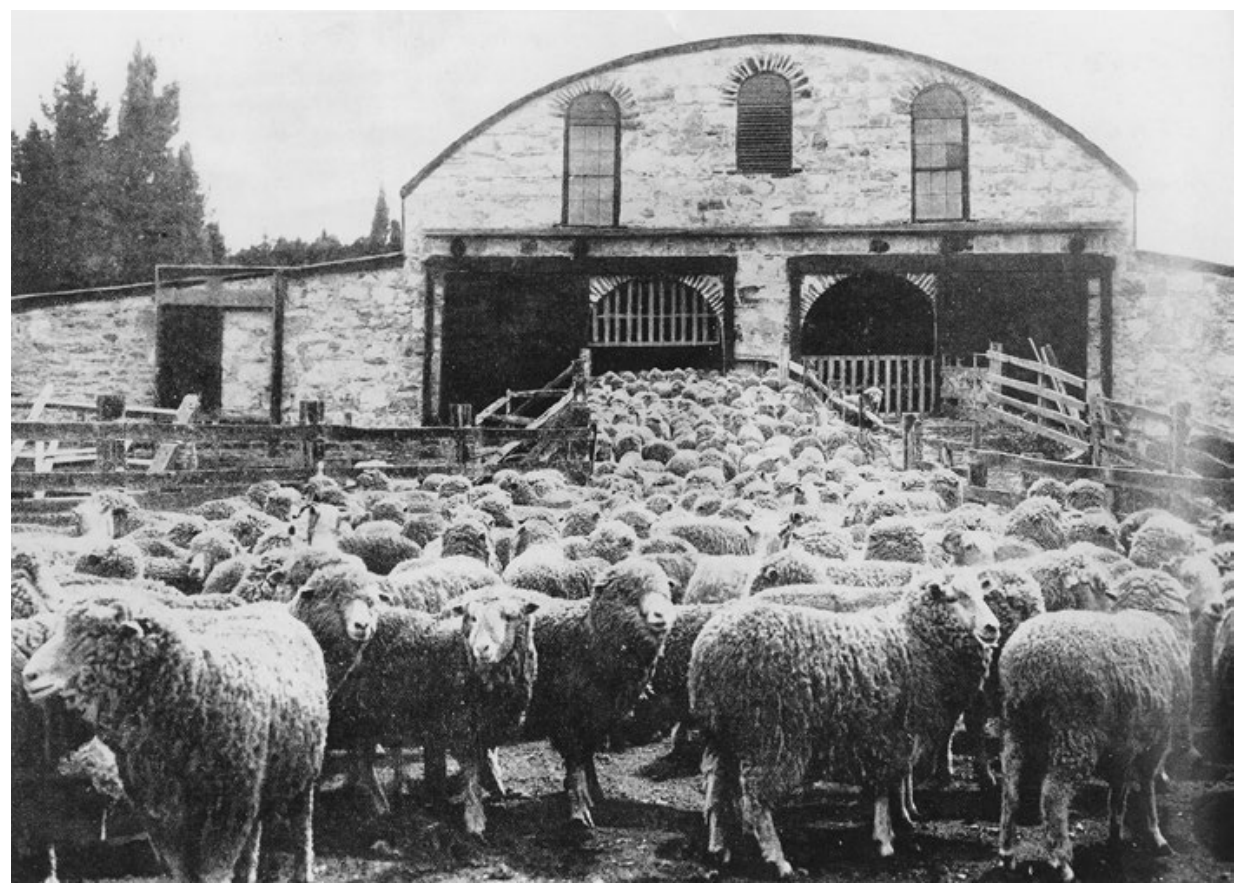

Photo 1: Sheep recently mustered from the hill country and held in the yards waiting to be shorn, Teviot Station, Central Otago, Otago Witness, 10 February 1904, 38.

Source: Hocken Collections, Uare Taoka o Hākena, University of Otago, c/nE5259/20A.

14 O. Jones, 'Non-human rural studies', in P. Cloke, T. Marsden and P. Mooney, Handbook of Rural Studies (London: Sage, 2006), 185-202; O. Jones and P. Cloke, 'Non-human agencies: trees in place and time', in C. Knappett and L. Malafouris, Material Agency: Towards a Non-anthropocentric Approach (New York: Springer, 2008), 79-96. 
An element of ecological theory, the succession model as applied by the French-Canadian plant ecologist, Pierre Dansereau, underpinned our approach and methods. ${ }^{15}$ The core notions of plant succession are rooted in research undertaken in the United States in the late nineteenth and early twentieth centuries, particularly the studies of Henry Cowles on sand dunes flanking Lake Michigan, the proposals of H. C. Gleason a decade later about the end-point of a succession, and the investigations of Frederick Clements in the Oklahoma dustbowl. ${ }^{16}$ Succession theory postulates an orderly sequence of steps in the establishment of mature vegetation cover on a newly exposed area of bare rock or mineral sediment. Initially, fast-growing and short-lived plants with seeds that germinate in full sun on bare ground, low biomass, high productivity, and broad niches will predominate. ${ }^{17}$ This pioneer system allows larger, longer-lived and slower-growing plants to become established, and progressively gives way to structurally complex systems with smaller and more specialised niches as well as greater biodiversity. Since the 1980s, after several decades of probing debate, successional studies have reappeared in the ecological literature. ${ }^{18}$

Dansereau knew about the findings of research into the secondary successions ${ }^{19}$ that develop after forest clearance, landslide, erosion, cultivation, or fire, including old field systems triggered by farm abandonment. ${ }^{20} \mathrm{He}$ viewed a productive farm as a managed ecological system occupying ground that had been wholly or partly bared by cultivation before being sown with commercial varieties of herbaceous and woody plants to ensure food for people and grazing for domesticated animals. Among his proposals was that an agro-system is home to short-lived plant and animal species selected for their high fecundity,

15 The French-Canadian plant biogeographer, ecologist, and environmentalist Pierre Dansereau was born in 1911 and received his initial university education in agricultural science. He became known in Canada and abroad for his research into the structure, composition, and dynamics of forest vegetation, which he taught in several North American universities. In 1972, after a decade as assistant director of the New York Botanical Garden, he returned to Montreal where he undertook and directed research in the burgeoning field of environmental studies from a base at the Université du Québec à Montréal. In later life, his prime concern was to show how ecological principles apply to the human environment, and a corner-stone of his approach was that a farm is a special type of ecological system. In 1988, Peter Holland attended a presentation in Montreal by Professor Dansereau about relations between agro-systems and ecology. The latter died in 2011, a few days short of his 100th birthday.

16 F. E. Clements, Plant Succession and Indicators (New York: H. W. Wilson, 1928); H. C. Cowles, 'The ecological relations of the vegetation of the sand dunes of Lake Michigan', Botanical Gazette (1899); H. C. Gleason, 'The causes of vegetation cycles', Annals of the Association of American Geographers 1 (1911): 3-20. D. Worster, Nature's Economy: A History of Ecological Ideas, 2nd ed. (New York: Cambridge University Press, 1994) is the classic reference work on the role of ecological thinking in environmental history.

17 C. Gibson and V. Brown, 'Plant succession: theory and applications', Progress in Physical Geography 9 (1985): 473-93.

18 J. P. Sullivan, P. Williams and S. Timmins, 'Secondary forest succession differs through naturalised gorse and native kanuka near Wellington and Nelson', New Zealand Journal of Ecology 31 (2007): 22-38.

19 F. B. Golley, Ecological Succession (Stroudsburg, PA: Halstead Press, 1977).

20 F. A. Bazzaz, 'Succession in abandoned fields in the Shawnee Hills, Southern Illinois', Ecology 49 (1968): 924-36. 
palatability, and rapid growth, all of them demanding of water, nutrients, and other environmental resources. To Dansereau, the managed ecological systems of a farm or station are analogous to the early stages of a secondary succession, except that human agency has populated them with a small number of specially selected species, controlled irruptions of weedy plants and pest animals, limited predation, and supplemented local environmental resources.

We suggest that the notions of environmental and social resilience ${ }^{21}$ are also informative: the former is a measure of the capacity of a mature ecosystem to recover to something approaching its prior state after damage wrought by animate and inanimate forces, while the latter reflects the capacity and ability of individuals to survive and make progress after an economic or environmental set-back. We argue that these qualities, in combination with the notions of human and non-human agency and the enlistment of ecological thinking, open a window onto the problems experienced by early farm and station holders with gorse, rabbits, and thistles during and after episodes of gross environmental disturbance in southern New Zealand.

Our primary sources were the records maintained by nineteenth-century European land holders in southern New Zealand, notably daily records kept by one or two residents of individual properties over periods of at least five years. In their diaries and letter books, land holders, and managers recorded the nature of work done on the property and by whom. Even though these requirements reduced the number of documentary sources available to us, we were able to locate seven runs of diaries or letter books that contained details of land transformation in the principal environments of the South Island open country: (a) the diaries of James Murison of Puketoi Station near Patearoa in the Maniototo; (b) the journal of the Phillips family, whose sheep station, The Point, lay on the north bank of the Rakaia River a short distance from Windwhistle in mid-Canterbury; (c) the diaries of Joseph Davidson, who farmed a 500-acre block on the outskirts of Waikaia in northern Southland; (d) the diaries of John Wither, who held leases on three adjoining blocks of mostly pastoral land across Lake Wakatipu from Queenstown; (e) the diaries of David Wallace, who farmed near Clinton in eastern Southland; ( $f$ ) the diaries and personal papers of James Preston, who held leases on properties in the Maniototo, the upper Waitaki Valley, and the Mackenzie Country; and (g) the National Mortgage \& Agency

21 F. S. Chapin III, S. R. Carpenter, G. P. Kofinas, C. Folke, N. Abel, W. C. Clark, P. Olssen, D. M. Stafford Smith, B. Walker, O. R. Young, F. Berkes, R. Briggs, J. M. Grove, R. L. Naylor, E. Pinkerton, W. Steffen, and F. J. Swanson, 'Ecosystem stewardship: sustainability strategies for a rapidly changing planet', Trends in Ecology and Evolution 25 (2010): 241-49. 
Company Ltd. (hereafter NMA) archive. ${ }^{22}$ Other information came from land company records, local and national government publications, the minute books of road, rabbit, and pest destruction boards, and newspaper articles. The mixture of formal and informal, printed, and manuscript sources for a property enabled us to calculate the time expended in man-days per annum on (a) burning, draining, ploughing, and other forms of gross environmental disturbance, (b) clipping hedge plants, chipping volunteer growth, and burning the trimmings, (c) eradicating rabbits, and (d) chipping or uprooting thistles.

\section{Pioneer farms and stations as ecological systems}

The prime challenge for a settler family was to establish sufficient grazing and arable land to ensure a satisfactory income, and this called for environmental transformation by spade and shovel, axe and saw, fire and plough. European settlers in the open country of southern New Zealand occupied an area that had been substantially transformed from a wooded landscape with the aid of fire set several centuries earlier by Polynesian hunters. In the 1840s and ' 50 s the open country might still have been recovering from environmental disturbance, but European settlers encountered an apparently natural landscape occupied by a small number of herbaceous species, tall and short tussock grasses, low shrubs, and trees in moist ground sheltered from the drying north-west winds of spring and summer. Sown pastures or crop-land could lift average carrying capacity from less than one to between five and 10 sheep per acre, and this objective was achieved by burning and cultivation followed by sowing judicious mixtures of grass and herbaceous broad-leaf species imported from Australia, Western Europe, and North America (Photo 2). In the drive to meet their economic goals, settlers damaged or destroyed indigenous ecosystems that were well suited to prevailing environmental conditions, and replaced them with shortterm habitats of disturbance created and regularly renewed by land holders. One early consequence was a reduction in biomass, but another two outcomes were a shift from tall to short tussock and loss of the palatable fine grasses and broad-leaf herbs that had occupied sheltered ground between tall tussocks. ${ }^{23}$

\footnotetext{
22 Except for The Point Journal, a copy of which is in the Canterbury Museum and Archive, Christchurch, the key sources are held by the Hocken Collections, Uare Taoka o Hākena, University of Otago: Joseph Davidson's diaries (AG-523 and MS-3983); John Wither's diaries (89-149); David Wallace's diaries (MS-4031); James Murison's diaries (ARC-0359); James Preston's diaries, personal and financial papers (MS-1271 and MS1272); the National Mortgage \& Agency Co. archive (UN-028).

23 Holland, O'Connor and Wearing, 'Remaking the grasslands of the open country'.
} 


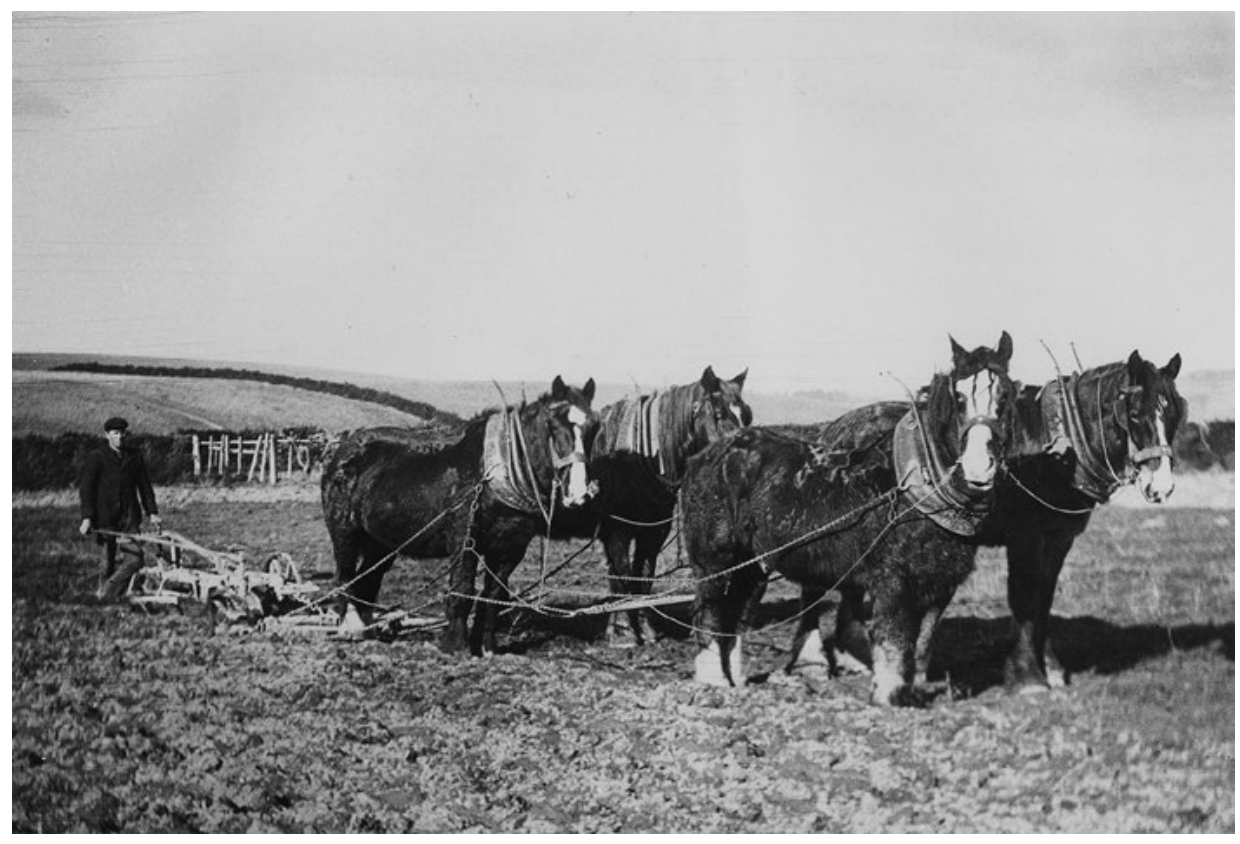

Photo 2: Alexander Dewar with a single-furrow plough drawn by a team of four draught horses on the New Zealand \& Australian Land Company's Totara Farm Estate, north Otago, c. 1910-15.

Source: Hocken Collections, Uare Taoka o Hākena, University of Otago, negE1649/41.

Whether partial or substantially complete, environmental transformation created ecological opportunities for introduced and native early successional species to become established and thrive, and settlers had to learn how to minimise any adverse effects. Settlers also modified, and in some places eradicated, prior environmental features by altering their character, dimensions, and placement, thereby setting the stage for further spontaneous changes. The outcome was a dynamic mosaic of old and new ecological subsystems, the fine structures of which comprised environmentally and ecologically distinctive places, lines, and surfaces, some of them entirely artificial, others showing few direct or indirect effects of people, and the remainder intermediate between those two states.

Throughout the south, settlers occasionally incorporated extant features in the new rural landscape: patches of remnant forest and shrubland in gullies, riparian vegetation alongside creeks and streams, tracts of tussock, areas of bracken fern and low shrubs, and large and small areas of wetland. Fields cleared for pasture, grain, and root crops, and delineated by rights-of-way, fences, hedges, stone and sod walls, or rows of trees (Photo 3) offered refuge, ecological opportunities, and pathways through the landscape for introduced as well as native plant and 
animal species. ${ }^{24}$ Widespread and repeated environmental disturbance was a distinguishing feature of the rural landscape. Fields of grain and potatoes were renewed annually, sown pastures often had to be replaced every three to five years, and all required persistent management.

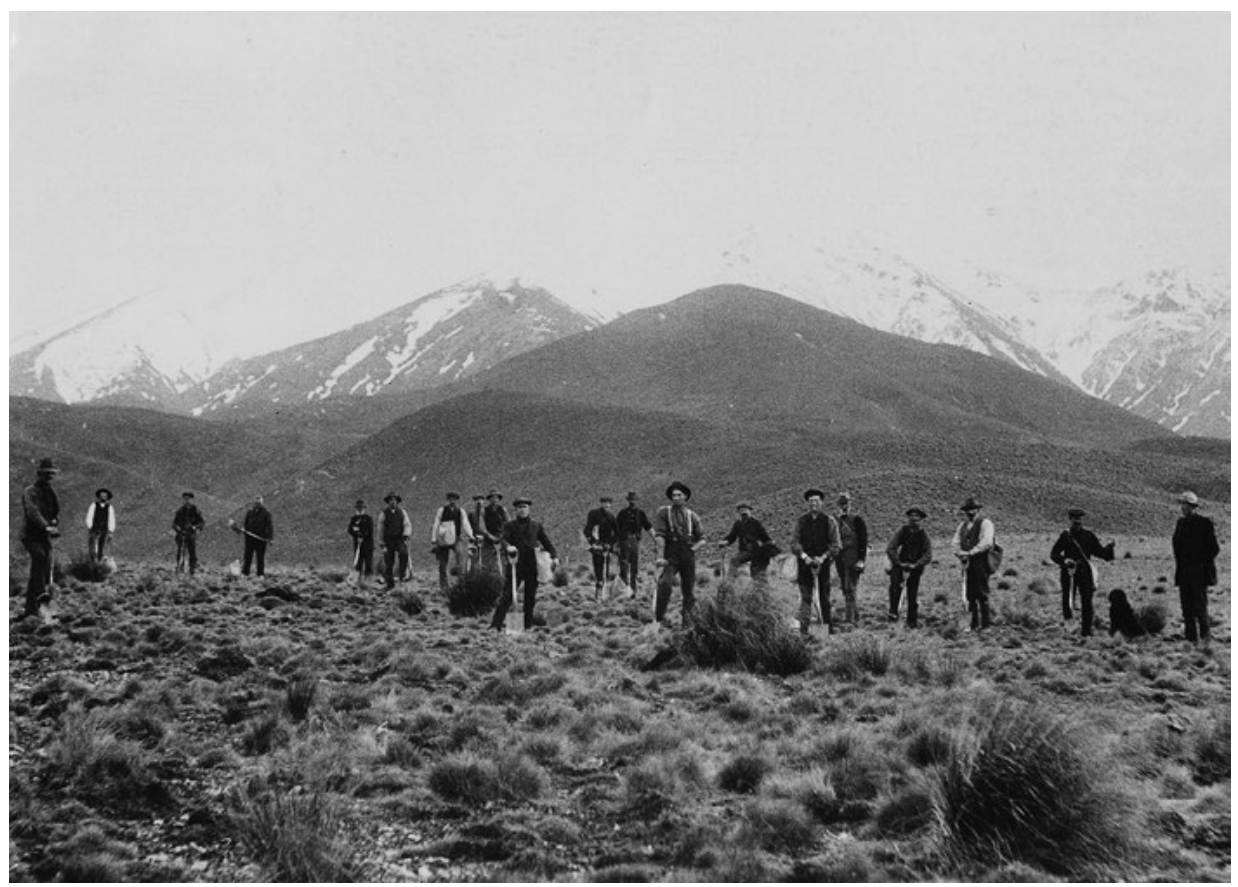

Photo 3: Tree-planting in the Maniototo, Otago, c. 1904

Source: Hocken Collections, Uare Taoka o Hākena, University of Otago, E402/3/5.

The immediate benefits of environmental transformation were improved carrying capacity for sheep and cattle, and a greater income from sales of wool, tallow, skins, meat, grain, hay, and root crops. In the long term, however, the modes of environmental transformation practised by settlers gave rise to unanticipated environmental and economic costs: infestation by and rampant growth of weedy plants, more pest animals, reduced carrying capacity for livestock, smaller economic surpluses, loss of plant nutrients, and soil erosion. The pace of seasonal and inter-annual change in a farm or station system was also more rapid and of greater amplitude than in the ecological system it replaced.

24 E. Pollard, N. W. Moore and M. D. Hooper, Hedges (London: Collins, 1974) is the classic account of research into the environment and ecology of hedgerows in the British Isles, and their significance as habitats and dispersal routes for plants and animals. 


\section{A century of gorse, rabbits, and thistles in southern New Zealand}

Gorse seed was commercially available in the second half of the nineteenth century, ${ }^{25}$ rabbits were introduced repeatedly after the mid-1840s, and thistle seeds, like those of many other weeds of agricultural and pastoral land, reached the Colony and spread as pollutants in sacks of grass seed..$^{26}$ Thistles thrived in ploughed ground, quickly became established, and dispersed as their ripe seeds were carried off by the wind. In the first two decades of organised settlement, these newcomers did not raise particular issues for land holders, ${ }^{27}$ and farm and station diaries, as well as settlers' letter books from that period, contain few references to them. This was soon to change.

\section{Gorse}

Gorse had been sown for hedges in the provinces of Taranaki and Nelson in the 1850s, and in 1859, when the Furze Ordinance became law, it was a recognised nuisance in the former. Two years later, the Nelson Provincial Council passed a similar ordinance prohibiting the use of gorse for hedges in Nelson city and requiring land holders to clip existing gorse hedges. ${ }^{28}$ Despite this, until the 1880s gorse remained the hedge plant of choice in eastern and southern districts of the South Island where there were limited supplies of native timber for fence-posts and rails, let alone for lumber and fuel. Supplies of imported gorse seed were advertised in newspapers and catalogues by merchants in towns and cities. Within a decade, gorse had become a common weed on land below 700 metres and was spreading into cultivated fields and environmentally disturbed tussock grass and shrubland, as well as occupying the banks and flood-worked gravel beds of lowland streams and rivers, from which it spread onto farm-land. Its seeds could remain viable in the top soil for two or three decades.

By the 1880s, land holders were discovering that the disadvantages of a gorse hedge outweighed its benefits, and the South Molyneaux District Road Board informed a prospective tenant that he was not permitted to plant gorse on the property. ${ }^{29}$ The Second Schedule of the Noxious Weeds Act (1900) listed gorse as a noxious weed, and the Noxious Weeds Act (1908) required 'Every occupier

25 Peter Holland, 'Plants and lowland South Canterbury landscapes', New Zealand Geographer 44 (1988): 50-60.

26 Herbert Guthrie-Smith, Tutira: the Story of a New Zealand Sheep Station, 3rd ed. (Edinburgh: Blackwood, 1953; 1st publ. 1921), 250.

27 A. W. Crosby, Ecological Imperialism: The Biological Expansion of Europe, 900-1900 (Cambridge: Cambridge University Press, 1986).

28 G. M. Thomson, The Naturalisation of Animals and Plants in New Zealand (Cambridge: Cambridge University Press, 1922).

29 Clutha County Clerk to A. J. Paterson, 12 June 1882, Hocken Collections, Uare Taoka o Hākena, University of Otago AG-253-007/001. 
of land' on which there are 'hedges or live fences, consisting of noxious weeds ... being sweetbriar [Rosa sp.] or blackberry [Rubus sp.], and also gorse [Ulex europaeus], broom [Cytisus scoparius] or hakea [Hakea sp.] ... (wherever the same are declared to be noxious weeds... and not forming portion of a hedge or live fence) ... shall' either clear if in small patches or 'shall clear the same at the proper season of the year along the entire length of every boundaryfence or boundary-line, and on each side of every internal fence, water-race, or watercourse to the width of at least one-quarter of a chain each year until the whole is cleared. ${ }^{30}$ Assiduous land holders trimmed hedges after flowering to constrain seed production, and grubbed out self-sown broom and gorse.

\section{Rabbits}

There have been numerous publications about the initial release, spread, and establishment of rabbits in New Zealand..$^{31}$ They include accounts of how land holders and government agencies later sought to develop and employ a suite of physical, policy, and legislative tools to control the pest.

In January and August 1858 W. K. Macdonald released European rabbits in the lower Orari River valley, south Canterbury, as well as on a nearby stretch of coastal sand dunes. The following year their progeny were sufficiently numerous for family members to shoot them for sport. ${ }^{32}$ The Macdonalds were not the first and would not be the last settlers to do so. G. M. Thomson noted that while early introductions of rabbits in the eastern and southern South Island either failed or the animals did not spread, later introductions were more invasive. ${ }^{33}$ Between the late 1840s and the mid-1870s, rabbits spread from where they had been released, typically following railway rights of way, road verges, and river valleys to occupy environmentally disturbed habitats in farm and station:

I think it is quite time something was done to have the rabbits destroyed in the Ahuriri [River, a tributary of the Waitaki River] on the islands between the ford and top of our run paddocks [where] they are swarming. They are also thick all over the Omarama flat ... The rabbits will take to the water when hard pressed. That is how they came to the mainland..$^{34}$

\footnotetext{
30 'Noxious Weeds, 1908, No. 133', 440-447: www.enzs.auckland.ac.nz/docs/1908/1908C133.pdf.

31 Four notable examples are: J. Druett, Exotic intruders: the introduction of plants and animals into New Zealand (Auckland: Heinemann, 1983); J. A. Gibb and M. J. Williams, 'The rabbit in New Zealand', in The European Rabbit: The History and Biology of a Successful Colonizer, ed. H. V. Thompson and C. M. King (Oxford: Oxford University Press, 1994), 158-204; B. Reddiex and G. Norbury, 'European rabbit', in The Handbook of New Zealand Mammals, ed. C. M. King (Melbourne: Oxford University Press, 2005); K. A. Wodzicki, Introduced Mammals of New Zealand: an Ecological and Economic Survey, Bulletin No. 98 (Wellington: Department of Scientific and Industrial Research, 1950).

32 W. K. Macdonald's diary, Orari Station, original in private hands.

33 Thomson, The Naturalisation of Animals and Plants, 85-87.

34 Manager's letter book, Benmore Station, 23 July 1874, Hocken Collections, Uare Taoka o Hākena, University of Otago, MS-3766.
} 
The leaseholder of a station on the shores of Lake Wakatipu recorded in his diary that rabbits had recently spread to the property and by January 1875 were 'becoming numerous'. On 27 February 1877, he reported killing 42 rabbits. ${ }^{35}$ His neighbour, John Wither, had seen large numbers of feral rabbits in northern Southland, about 50 kilometres from his home, in September 1877 and found them on his own property a few months later. ${ }^{36}$ On 12 January 1878 and again on 11 April, James Preston recorded that visitors to Haldon Station 'went after [that is, hunted] rabbits in the [Ahuriri] river bed'.$^{37}$ Three years later, the entire station was plagued by rabbits. The Scottish manager of Ida Valley Station in Central Otago wrote to the absentee leaseholder on 2 August 1882: 'this drought, together with the rabbits, has made the ground very bare' ${ }^{38}$ The following April, he noted a large increase in the number of rabbits, and a major decline in pasture growth, on the station, despite good growing conditions for introduced pasture grasses.

Although rabbits preferred sown pastures, they also ate the roots of tussock grasses, shrubs, and perennial herbs, and gnawed cabbage-tree trunks. ${ }^{39}$ On 22 May 1889, W. C. Scrimgeour wrote to the General Manager of the NMA about rabbits on Lake Ohau Station on the flanks of the Southern Alps:

As yet, the rabbits have not injured the feed, although they have begun to dirty the ground in places ... [but] when the rabbits increase to such a point as will affect the autumn conditions of stock (and this is likely in such country) then the loss of sheep during winter will be phenomenal. ${ }^{40}$

He believed that this would happen within five years, and expressed concern lest rabbits spill over from the headwaters of the Waitaki River into the upper catchment of the Rangitata River. Much the same concern had been expressed by the writers of a report presented to parliament three years earlier. ${ }^{41}$

The economic and environmental impacts of rabbits were quickly recognised, ${ }^{42}$ but how they reached plague densities in the drier country of the central South Island has been debated for decades. G. M. Thomson believed it unlikely that the sparsely vegetated landscapes of Central Otago were

\footnotetext{
35 Diary, Mt. Nicholas Station, Hocken Collections, Uare Taoka o Hākena, University of Otago, MS-0672.

36 John Wither's diary, Sunnyside Station, Hocken Collections, Uare Taoka o Hākena, University of Otago, 89-149.

37 James Preston's diary, Haldon Station, Hocken Collections, Uare Taoka o Hākena, University of Otago, MS-1271/074.

38 Manager's letter book, Ida Valley Station, Hocken Collections, Uare Taoka o Hākena, University of Otago, MS-0658.

39 Appendices to the Journals of the House of Representatives (hereafter AJHR), I-6, 1881.

40 NMA miscellaneous papers, Hocken Collections, Uare Taoka o Hākena, University of Otago, shelf 785D, parcel.

41 'Report of the Joint Committee on Rabbit and Sheep Acts', AJHR, I-4, 1886.

42 D. Petrie, 'Some effects of the rabbit pest', New Zealand Journal of Science 1 (1883): 412-14.
} 
brought about by rabbits alone. Before their advent, the runholders who had possession of the arid region ... were doing their best to denude the surface of the ground by overstocking with sheep and frequent burning. ${ }^{43}$

The first rabbit 'plague' peaked in the 1890s. Leaseholders were responsible for eradicating rabbits, but the rabbiters employed under contract were suspected of destroying predators and merely culling the rabbits. Eradication of rabbits was initially the responsibility of individual land holders and organised at the local level. ${ }^{44}$ In the ironic words of one land holder, 'If you want to breed rabbits, keep rabbiters' ${ }^{45}$ Except where successful steps had been taken to eradicate them, large populations of rabbits persisted on Crown and Māori land, and in the final two decades of the nineteenth century, iwi (tribes) were suspected of introducing rabbits to previously unaffected areas as a wild food source. ${ }^{46}$

The first Rabbit Nuisance Act became law in 1876, and under the Rabbit Nuisance Act (1881) New Zealand was divided into districts, each with an inspector charged with the eradication of rabbits. In their annual reports to parliament, inspectors declared their faith in 'natural predators' - primarily introduced cats, ferrets, stoats, and weasels - as a solution to the rabbit problem, and advocated 'stringent protection of the native weka [Galliralus australis] as the best natural enemy to the rabbit we possess' ${ }^{47}$ When rabbit skins realised good prices on local and overseas markets, some land holders restricted rabbit extermination to the winter months when the skins were most valuable. Rabbiters also protected their livelihood:

The price paid for rabbits is so good that it is a very great inducement [for rabbiters] to preserve the rabbits throughout the summer when they are of little or no value, and great difficulty is often experienced in getting thorough poisoning done, all sorts of schemes being adopted to hoodwink the [rabbit] inspectors. ${ }^{48}$

A further source of annoyance for government officials was the inducement paid to land holders by the owners of rabbit canning factories (Photo 4) to cease laying poison and only trap animals in their seasonal prime. ${ }^{49}$

\footnotetext{
43 Thomson, The Naturalisation of Animals and Plants, 92.

44 Under the Rabbit Nuisance Act (1876), properties within a rabbit district were subject to inspection by government employees with power to levy fines and lay formal charges if the work was unsatisfactory. This system continued until the formation of the national-level Rabbit Destruction Council under the Rabbit Nuisance Act (1947) and the Rabbit Act (1956). Rates were levied on land holders in areas that were the responsibility of a rabbit board or, from 1967, an agricultural pest destruction board. These charges were to cover the costs of materials and staff wages. This system remained largely in place until 1989, when agricultural pest destruction boards were brought under the control of regional councils and the Rabbit and Land Management Programme (RLMP) was inaugurated. The RLMP ran from 1989 to 1995, and its activities concerned individual properties rather than broad geographical areas. Regional and district councils currently have oversight of the rabbit nuisance as well as powers of enforcement under the Biosecurity Act (1993). Responsibility for rabbit eradication, however, was returned to individual land holders.
}

45 AJHR I-5, 1888, 129.

46 AJHR, I-11, 1889.

47 AJHR, H-18, 1887

48 AJHR, H-21, 1891.

49 AJHR, H-19, 1892. 


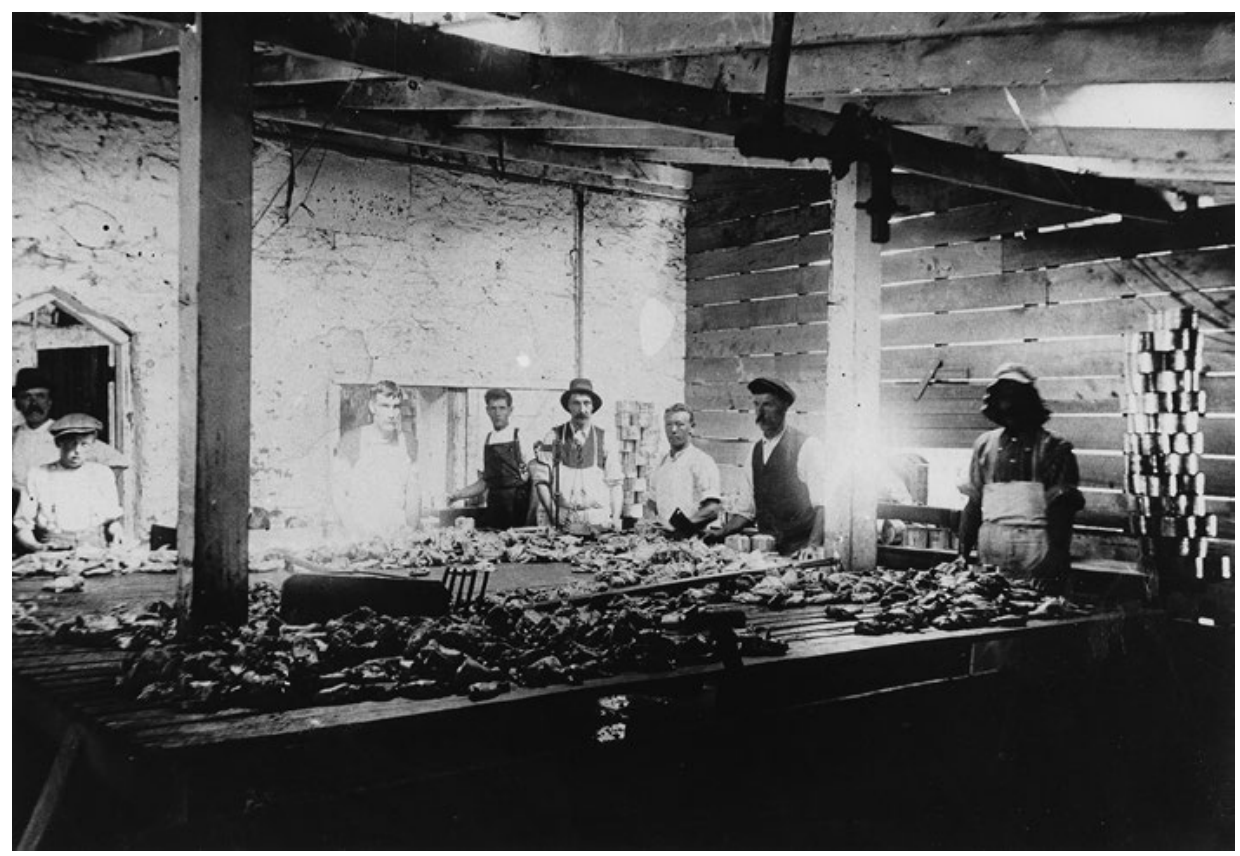

Photo 4: Employees and the interior of a rabbit canning factory at Alexandra, Central Otago, 1917.

Source: Hocken Collections, Uare Taoka o Hākena, University of Otago, c/nE1472/5.

Trapping, shooting, and poisoning, like hunting with dogs and ferreting, reduced rabbit numbers in cultivated land and sown pastures, but the pest found refuge in tracts of partly transformed tussock grass and shrublands, along the banks and in the seasonally dry gravel beds of rivers and streams, as well as in the sod walls that the first-generation European settlers had erected to partition their properties. They also thrived under gorse and broom hedges, in the shelter of bracken fern and matagouri (Discaria toumatou), and in rampant growths of gorse and broom along roads and railway rights of way. By the early 1880s, a land holder's task had changed from the simple eradication of rabbits wherever they might be on the property to a more targeted strategy of reducing or clearing refuge areas, controlling access to palatable herbage, killing as many animals as was possible, and discouraging survivors from breeding. This involved labourintensive work in the environmental patches, bands, and surfaces of a property and, as a superintending inspector reported to parliament, 'in shearing and harvest time the difficulty of obtaining hands, together with the rapidity with which the rabbit increases at this season, to a great extent nullifies the autumn and winter efforts'.$^{50}$ 
In Central Otago, periodic conjunctions of drought and large numbers of rabbits left the ground almost denuded of palatable shoots for sheep and cattle, allowing populations of rabbits to become re-established a few months after intensive shooting and poisoning had virtually eradicated them from a property. In his letter book, the manager of Ida Valley Station recorded in early December 1882 that rabbits were thriving in the depleted rangeland, browsing regenerating herbs and fine grasses before they could recover sufficiently to support the normal number of sheep, and 'breeding at a fearful rate' after several months of drought. ${ }^{51}$ The writer also suspected that intensive poisoning of rabbits had lifted the normal winter death rate among his sheep by half a point to 3.1 per cent. ${ }^{52}$ The situation had improved by 1886 , but he feared a resurgence in rabbit numbers after two years of intensive poisoning because the depleted vegetation cover had not had sufficient time to recover. ${ }^{53}$

In the 1890s, frequent episodes of stormy weather and intervening mild spells took place alongside economic depression, leading to fluctuating numbers of rabbits on back-country properties. Mild, moist winters, in contrast, ensured good pasture growth for sheep, but unfavourable conditions for young rabbits, which usually did better in cool, dry winters when snow and severe frost did not mask herbage and cause starvation. ${ }^{54}$

How did settlers attempt to control rabbit numbers? A former naval man, Captain J. W. Raymond of Southland, claimed to have been the first to dress oats with phosphorus for poisoning rabbits. ${ }^{55}$ Phosphorus was sold in sealed cans, usually containing six pounds of the substance, by rural supply companies. Another two poisons, arsenic and strychnine, were available from pharmacies and land companies. In the late nineteenth century, when phosphorised pollard was preferred, farmers could buy it ready-mixed, although rural people were still mixing their own supplies in the first decade of the twentieth century. ${ }^{56}$ Land holders in areas infested by rabbits found it an unpredictable poison. In some seasons it was freely taken by rabbits, but at other times and in different habitats the animals would not touch it. In 1896, the manager of Ida Valley Station recorded in his letter book that he was 'not at all satisfied with the results of poisoning - plenty of poison laid but great numbers of rabbits

\footnotetext{
51 Manager's letter book, Ida Valley Station, 1 December 1882, Hocken Collections, Uare Taoka o Hākena, University of Otago, MS-0658.

52 Ibid., letter dated 8 April 1885.

53 Ibid., letter dated 1 November 1886.

54 Peter Holland, Home in the Howling Wilderness: Settlers and the Environment in Southern New Zealand (Auckland: Auckland University Press, 2013), 51.

55 In addition to a long article published by The Argus (Melbourne) on 3 March 1881, several articles and letters to the editor about Raymond's claim were published by the Southland Times (Invercargill), notably on 4 November 1880 and 21 February and 7 October 1884.

56 Holland, Home in the Howling Wilderness, 154.
} 
[remain] on Poolburn face and elsewhere'.$^{57}$ Three years later, he could report to the absentee leaseholder: '[I] did not see many rabbits ... the poisons seemed to be clearing them well' ${ }^{58}$

During the plague years of the late nineteenth and early twentieth centuries, the preferred means of exterminating rabbits on farm and station were poisoning, trapping, shooting, and predation by the animal's 'natural enemy'. Ferrets and other mustelids were imported from Great Britain, bred by government establishments, and then sold to land holders for about seven shillings each. In the early days, ferrets were fastened to long leads and released in rabbit burrows. On some properties, wild populations of ferrets persisted for several years until they were decimated by tuberculosis and winter cold. Although the words 'ferret', 'stoat', and 'weasel' are common in official reports, newspaper articles, and private papers, the correctness of identification is uncertain. Governmental support for introduced 'natural enemies' waned when cats and mustelids spread into indigeneous ecosystems and began to predate on native birds and reptiles.

Land holders exploited the incidental benefits of stormy weather that caused rabbits to leave their burrows, or when floods drowned the animals or forced them into the open, where they could be shot. A habitat-centred approach to pest management was evident by the 1880s, when land holders cleared shrubby growth along property boundaries, burned bracken fern, and cleared shrubs from rough ground to reduce cover. The language used in advertising and promotional material relating to pest management on productive land was often militaristic in tone: aggressor, dominance, evil, invasion, and plague. ${ }^{59}$

Between the start of the First World War and the end of the Second, labour was expensive and rabbit eradication was largely directed by rabbit boards governed by representative groups of local land holders, who reported to the Department of Agriculture in Wellington. Individual and communal agency were involved in this, and while the prime driver of rabbit eradication was protection of pastures and range land as an economic resource, there were signs of a growing feeling of stewardship for indigenous plants and animals. By 30 September 1929, the manager of the Dunedin branch of the NMA could inform the Head Office in Edinburgh: 'Rabbits are practically exterminated in Central Otago, and this, together with irrigation, has completely changed the outlook of this large tract

57 Manager's diary, Ida Valley Station, 8 August 1896, Hocken Collections, Uare Taoka o Hākena, University of Otago, MS-0658.

58 Ibid., 3 March 1899.

59 Tom Brooking and Vaughan Wood, 'The grasslands revolution reconsidered', in Making a New Land: Environmental Histories of New Zealand, ed. Eric Pawson and Tom Brooking (Dunedin: Otago University Press, 2013), 193-208. 
of country.' ${ }^{60}$ The following decade, however, rabbit numbers again increased, and rabbit boards experienced a resurgence of intense activity. In the late 1940s, public meetings were called to discuss the rabbit problem and the recently promulgated national 'killer policy' ${ }^{61}$

\section{Rabbits and cover}

After the Second World War, rabbit board staff and contractors were experiencing difficulties with poisoned bait, one board reporting to the national Rabbit Destruction Council that 'carrots and strychnine poisoning have not this year been successful, and so far phosphorised pollard had also been a failure, and [we] request the Council to advise if any further results have been obtained from the investigations into a new poison' ${ }^{62}$ But a greater problem was the large amount of cover in the rural landscape. On 21 November 1951, a contractor tendered to clear lupins that were sheltering rabbits on dredge tailings, ${ }^{63}$ and in their efforts to rid one overgrown area of rabbits employees of the Cardrona Rabbit Board had to cut four lanes through a thick patch of broom and shoot in each block separately after packs of dogs had excavated burrows. ${ }^{64}$ The following month an inspector reported:

it has been a heavy breeding season; there is a lot of cover about this year, which makes it difficult to hole up rabbits for larviciding. ${ }^{65}$ We have a big patch of thistles on Dillon's property, impossible for men or dogs to work, so [we] have used [a] Landrover and mower to cut same, [being] the only possible way to get the rabbits out. ${ }^{6}$

The situation had become sufficiently serious for one board to petition the Department of Agriculture to carry out trials with myxomatosis in its district. ${ }^{67}$

The importance of habitat clearance in conjunction with poisoning and shooting led to the following remit being put to the vote at the July 1971 conference of the South Island Pest Destruction Board: As cover is proving a formidable barrier to

60 NMA miscellaneous papers, Hocken Collections, Uare Taoka o Hākena, University of Otago, UN-028, Box 288.

61 Manuherikia Rabbit Board minutes, 26 January 1949, Hocken Collections, Uare Taoka o Hākena, University of Otago, AG-631-5.

62 Kokonga-Tiroiti Rabbit Board minutes, 29 June 1951, Hocken Collections, Uare Taoka o Hākena, University of Otago, MS-1590.

63 Earnscleugh Rabbit Board minutes, 25 November 1951, Hocken Collections, Uare Taoka o Hākena, University of Otago, AG-744-02.

64 Cardrona Rabbit Board minutes, 6 December 1951, Hocken Collections, Uare Taoka o Hākena, University of Otago, AG-525-1.

65 Since the 1870s, chloropicrin gas, known as Larvicide, has been used to fumigate occupied rabbit burrows and warrens.

66 Cardrona Rabbit Board minutes, 31 January 1952, Hocken Collections, Uare Taoka o Hākena, University of Otago, AG-525-1.

67 Strath Taieri Rabbit Board minutes, December 1951, Hocken Collections, Uare Taoka o Hākena, University of Otago, AG-336-1. 
eradication for Boards, that government make available an increased subsidy on herbicides [which were then acknowledged as more effective in the long term than burning] for purposes of pest destruction by county councils. ${ }^{68}$ It failed, but throughout Otago, rabbit boards and the pest destruction boards which succeeded them found that rabbits were more numerous in, and more likely to return after shooting and poisoning to, land where gorse and broom hedges were common. The latter were described by one of those organisations as the 'major problem in flat country' ${ }^{69}$ Rabbit boards targeted places where the pest was numerous, and in view of the heavy infestation of rabbits in his district, one exasperated manager suggested 'that the area be bulldozed and ploughed to clear the gorse shelter from it' ${ }^{70}$ In the same spirit, an inspector employed by another board reported 'that the Shotover River bank was to be cleared up as soon as possible, and if necessary, additional labour was to be engaged to expedite the work ${ }^{\prime} .^{71}$

Removal of large and small areas of plant cover was seen as essential to managing rabbit numbers: plantations of trees with dense undergrowth, rampant broom and gorse hedges, patches of bracken fern, clumps of thistle, even sweet-briar, matagouri and cocksfoot, the 'terrific growth' of which was 'causing serious delay in gaining control over rabbits'.$^{72}$ This had been recognised in the 1890s, when the Superintending Inspector of Rabbits reported to Parliament that the Otago Rabbit District was experiencing a 'very serious spread of gorse and broom on river banks, mining reserves, public roads and unoccupied private lands'. Areas that had been cleared of rabbits a few months earlier were deemed at risk of reinfestation through occupation of and dispersal along lines of shrubs and tall grass on stream banks as well as gorse and broom in river beds. ${ }^{73}$ The July 1956 Minutes of the Taieri Ridge Rabbit Board recorded:

68 Silver Peaks Pest Destruction Board miscellaneous papers, Hocken Collections, Uare Taoka o Hākena, University of Otago, 97-156.

69 Blackstone Pest Destruction Board minutes, 2 February 1973, Hocken Collections, Uare Taoka o Hākena, University of Otago, AG-330-2.

70 Strath Taieri Rabbit Board minutes, March 1950, Hocken Collections, Uare Taoka o Hākena, University of Otago, AG-336-1.

71 Lake Wakatipu Rabbit Board minutes, 11 June 1951, Hocken Collections, Uare Taoka o Hākena, University of Otago, AG-237.

72 Lake Wakatipu Rabbit Board minutes, 14 February 1955, Hocken Collections, Uare Taoka o Hākena, University of Otago, AG-237.

73 Manuherikia Rabbit Board minutes, 10 November 1954, Hocken Collections, Uare Taoka o Hākena, University of Otago, AG-631-5; Cairnhill Rabbit Board minutes, 24 August 1955, Hocken Collections, Uare Taoka o Hākena, University of Otago, AG-746-01; Leaning Rock Rabbit Board minutes, 6 May 1957, Hocken Collections, Uare Taoka o Hākena, University of Otago, AG-747-2; Cardrona Rabbit Board minutes, 7 August 1959, Hocken Collections, Uare Taoka o Hākena, University of Otago, AG-525-1). For comments on gorse hedges as sources of self-sown plants in railway rights-of-way see Cardrona Rabbit Board minutes, 2 February 1956, Hocken Collections, Uare Taoka o Hākena, University of Otago, AG-525-1. 
The increasing growth of rough cover in the gullies was discussed by members who considered that the only satisfactory method of clearing these gullies of rabbits was to burn out the scrub. This would leave the gully in an open condition for some seasons and prevent 'pockets' of rabbits from accumulating there. ${ }^{74}$

The situation in the 1960s indicated little change in 70 years. Large and small areas of rough ground, along with belts of cover and piles of hedge clippings and orchard-tree prunings, were targeted for clearance. One inspector reported that 'a greater number of young rabbits appeared to have survived this year due to the use of 1080 and Larvicide which destroyed the natural enemy [cats, hawks, and mustelids], plus the exceptionally dry season'.$^{75}$ In 1962, the secretary of a rabbit board in eastern Otago was directed to advise the local county council that rampant gorse and broom on road lines were hampering the board's efforts to eradicate rabbits, and that viable seeds of these two noxious weeds were reaching previously clean areas in loads of river shingle collected by council workers for road repair. ${ }^{76}$ Another inspector reported seeing 'the odd rabbit in quite heavy tussock, and when followed these rabbits do not appear to have any warren or hole to go to, but appear to live in the heavy tussock in the manner of hares' ${ }^{77}$ Rabbits were evidently exhibiting behavioural shifts that complicated the task of extermination. Large and small patches of cover offered refuge for rabbits, but rough ground alongside river courses and in valleys facilitated their persistence and dispersal.

Like land holders in the final two decades of the nineteenth century, rabbit boards used different eradication methods throughout the year, typically dogs, poisonous gases, phosphorised oats and pollard in summer, and aerial drops of carrots dressed with 1080 poison in winter. They, too, found that some poisons occasionally worked well while others were unreliable. ${ }^{78}$ The national Agricultural Pests Destruction Council believed that noxious weeds and agricultural pests went 'hand in hand', and that the elected rabbit destruction boards were the obvious and logical agents to undertake this work:

74 Taieri Ridge Pest Destruction Board minutes, July 1956, Hocken Collections, Uare Taoka o Hākena, University of Otago, 97-144.

75 Mid-Wakatipu Rabbit Board minutes, 6 February 1961, Hocken Collections, Uare Taoka o Hākena, University of Otago, AG-737. Sodium fluoroacetate ('1080') is a naturally occurring, toxic plant product present in a small number of species worldwide and deters herbivory. It has been produced commercially since the early 1940s and is widely used in New Zealand to eradicate feral rabbits, rats, stoats, and weasels.

76 Strath Taieri Rabbit Board minutes, 8 March 1962, Hocken Collections, Uare Taoka o Hākena, University of Otago, AG-336-1.

77 Cardrona Rabbit Board minutes, 6 May 1963, Hocken Collections, Uare Taoka o Hākena, University of Otago, AG-525-1.

78 For an account of the methods employed by professional rabbiters in the mid-twentieth century see W. H. McLean, Rabbits Galore - On the Other Side of the Fence (Wellington: Reed, 1966). For information about the more limited palette of methods currently employed for eradicating rabbits see National Pest Control Agencies, Pest Rabbits: Monitoring and Control Good Practice Guidelines (Wellington: National Pest Control Agencies, 2012). 
'Noxious weeds would be a greater menace than the rabbit pest, and Boards should look closely at this' ${ }^{79}$ The Council had correctly assessed the related risks posed by rabbits and noxious weeds, but few pest destruction boards were willing to take on the responsibility for controlling a second noxious organism.

In 1980, J. A. Powell reported that

the Wakatipu District is like many other parts of New Zealand where better land usage, development and better stock management are all against the rabbit. The wetter season and better ground cover have been responsible for a marked decrease in rabbit numbers where no control work has been done on several areas in this district. ${ }^{80}$

In a further report to the same body, Powell recommended: 'because of the amount of cover, [bracken] fern, briar, brush weeds, matagouri etc, neither trapping nor shooting of any sort [should be undertaken] and ... the rabbits [should be left] completely alone until they can be oat poisoned' ${ }^{81}$ Significantly, he recognised that opportunistic plant species, native as well as introduced, could thrive in the environmentally disturbed habitats of a transformed landscape and harbour other early successional plants and pest animals. Four years later, Powell showed a deeper ecological understanding of rabbit infestation when in his confidential report to Central Otago Pest Destruction Boards he stressed the importance of understanding rabbit behaviour:

Odd places, actually, showed a decrease in rabbits without any control having been applied. The removal of bracken fern, scrub manuka, and noxious brushweed cover, coupled with improved pasture, would be the reason for the decreased rabbit numbers in a number of places ... longer grass, when wet[,] has the same effect of destroying young rabbits. ${ }^{82}$

While they were learning to manage irruptions of rabbits on their land, individual settlers recognised the role played by self-sown and planted gorse in harbouring the pest. They also found that thistles, a noxious weed of pastures and crop-land, were also involved. The agricultural and pastoral systems that they had created were proving difficult and costly to manage, and Californian thistle would continue to challenge rural people in southern New Zealand until the 1950s, when hormone herbicides became commercially available.

79 Cardrona Pest Destruction Board minutes, 15 November 1972, Hocken Collections, Uare Taoka o Hākena, University of Otago, AG-525-2.

80 Wakatipu Coordinating Committee of the Agricultural Pests Destruction Council minutes, Hocken Collections, Uare Taoka o Hākena, University of Otago, 97-145.

81 Ibid., November 1980.

82 Confidential report to the combined Wakatipu, mid-Wakatipu, Glenorchy, and Upper Shotover Pest Destruction Boards: loose-leaf copy in the minutes of the Upper Shotover Pest Destruction Board, November 1984, Hocken Collections, Uare Taoka o Hākena, University of Otago, 97-145. 


\section{Thistles}

Entries in nineteenth- and early twentieth-century farm and station diaries frequently mentioned 'thistles', but rarely named the species. In New Zealand, most members of the Cardueae are thistles, but Californian thistle (Cirsium arvense), which was also known as Canadian thistle in the nineteenth century, ${ }^{83}$ apparently predominated. Nodding thistle (Carduus nutans) and Scotch thistle (Cirsium vulgare) might have become established later. ${ }^{84}$ The first of these is perennial and forms dense clumps with the aid of rhizomes; nodding thistle is annual or biennial, making it easier to eradicate by physical means; Scotch thistle is annual or biennial, and commonly found as a single plant. All three produce large quantities of wind-blown seed and grow in cultivated, disturbed, or waste ground, in pastures and gardens, on road verges and railway yards, and occasionally in environmentally disturbed tussock grassland. In 1922, G. M. Thomson described Californian thistle as 'sporadically all over the country in cultivated fields ... [and] particularly abundant and aggressive in half-cleared bush' ${ }^{85}$ On farms and stations in the South, thistles were controlled in pastures and crop-land by rolling, chipping, excavating, and burning until hormone sprays became commercially available.

Thistles probably reached southern New Zealand in cargoes of imported pasture plant seeds that were then spread by the wind, as pollutants in bags of seed, in the fleeces of sheep brought in from other parts of the country, or in mud on wheeled vehicles. In July 1928, the manager of the Ashburton branch of the NMA contacted a station manager to advise the availability of Alsike clover seed 'double-dressed to safeguard against the possibility of any Thistle seed' ${ }^{86}$ Once they had become established on a property, thistles thrived, flowered, produced heavy crops of seed, and spread rapidly. On 12 March 1878, the Cromwell Argus published a short piece about the abundance of thistledown in the Lake Wanaka area, and at the same time two farmers visiting New Zealand from Leicestershire reported thistledown landing on the deck of their steamer, two miles off the Hawke's Bay coast. They later described masses of thistledown blowing 'across the streets of Christchurch like a slight snow storm' ${ }^{87}$

83 Thomson, The Naturalisation of Animals and Plants, 425.

84 C. J. Webb, W. R. Sykes, and P. J. Garnock-Jones, Flora of New Zealand, vol. 4, Naturalised Pteridophytes, Gymnosperms, Dicotyledons (Christchurch: Botany Division, DSIR, 1988).

85 Thomson, The Naturalisation of Animals and Plants, 425.

86 Hakataramea Station inward letters, Hocken Collections, Uare Taoka o Hākena, University of Otago, UN028, Box 206.

87 S. Grant and J. Foster, New Zealand: A Report on its Agricultural Conditions and Prospects (London: G. Street, 1880), 20. 
Young thistles thrived in the nutrient-rich soils of newly-ploughed ground, and threatened to suppress broom and gorse seedlings, as well as the rooted cuttings of hawthorn, that settlers established in ploughed strips or on low banks of overturned sod for hedges. In the 1860s and '70s, farmers and station holders frequently noted in their diaries and letter books how hard it was to remove weeds from around a gorse seedling without damaging the young plant. On 15 November 1875, the manager of Taipo Hill station in North Otago informed the absentee land holder that 'the hedges which have been planted this year are all doing well so far [but] they take a lot of weeding. They are sometimes smothered with weeds and we dare not touch them for fear of pulling up the [hedge] plants. We must let them grow before we can weed them' ${ }^{88}$ Ten years later, settlers and property managers were recording in their diaries the heroic efforts needed to chip or uproot gorse and broom seedlings from fields and pastures, alongside roads and tracks, and in the beds of rivers and streams.

\section{Rabbits and sheep}

The close functional links between gross environmental disturbance, self-sown gorse, infestations of rabbits, and rampant growth of thistles are evident in farm and station diaries, the minutes of rabbit and pest destruction boards and other local body minutes, the published reports of national bodies, and newspaper articles (Table 1). Equally telling are long records of numbers of sheep shorn on a property and either the value or the number of rabbit skins sent away for sale. The latter two are fair surrogates for rabbit density because land holders were legally required to keep rabbit numbers down, properties were visited annually by government inspectors, and there were stern penalties for failing to eradicate the pest.

Table 1: Examples of the links between environmental disturbance, gorse, rabbits, and thistles.

\section{Environmental disturbance and gorse}

'James grubbing out whins [i. e. gorse] in West End Paddock' (David Wallace diaries, 4 September 1884).

'David chipping and burning whins [in partly cleared tussock] on Camping Spur' (David Wallace diaries, 28 April 1886).

'Johnnie Mitchell cutting down stray gorse growing from the fence' (Joseph Davidson diaries, 13 June 1894).

\section{Environmental disturbance and rabbits}

'Set 35 [rabbit] traps in Racecourse Paddock' (Joseph Davidson diaries, 10 August 1900).

'Shot rabbits on [recently] burned ground' (James Wither diaries, 25 September 1902).

'Mitchell got 44 rabbits out of Moffat's turnips' (Joseph Davidson diaries, 13 May 1904). 


\begin{tabular}{|c|}
\hline nvironmental disturbance and thistles \\
\hline 'Three [men] cut thistles and one grubbed in ploughed paddock' (David Wallace diaries, 11 January 1879). \\
\hline 'John ploughing small patches of Canadian thistles in swede paddock' (Cody family diaries, 17 April 1917). \\
\hline 'Cutting Scotch thistles out of fescue in top paddock' (Cody family diaries, 27 December 1949). \\
\hline Gorse and rabbits \\
\hline $\begin{array}{l}\text { 'The first case heard was a charge against A. Christie, of Brighton, who was charged with failing to } \\
\text { destroy the rabbits on his property.-Defendant pleaded not guilty.-R. Johnston, rabbit inspector, } \\
\text { stated that on September } 23 \text { his attention was drawn to the number of rabbits along the gorse } \\
\text { fences on the defendant's land at Brighton. Principally young rabbits were to be seen, and they were } \\
\text { there in large numbers. On the } 24 \text { th of September, accompanied by Stock-inspector Fullarton, [the] } \\
\text { witness visited the place, and rode over the sections. They found the gorse very thick, and they also } \\
\text { saw many young rabbits.' (Otago Witness, } 1 \text { December 1892). }\end{array}$ \\
\hline $\begin{array}{l}\text { 'I had a look around the gorse fence; got nine poisoned rabbits spoiled with the hawks'. (Joseph } \\
\text { Davidson diaries, } 3 \text { August 1903). }\end{array}$ \\
\hline $\begin{array}{l}\text { 'The road lines, gorse hedges and briars are becoming a bigger problem every year, and it is almost } \\
\text { impossible to get rabbits out of some of these areas' (Lake Wakatipu Rabbit Board minutes, } 14 \\
\text { February 1955). }\end{array}$ \\
\hline $\begin{array}{l}\text { 'The Board wrote to the Otago Catchment Board for a subsidy or other financial assistance to enable } \\
\text { the Board to eradicate the gorse on the river flats, and in particular the Von River flats where cover is } \\
\text { harbouring rabbits' (Mid-Wakatipu Rabbit Board minutes, } 19 \text { August 1963). }\end{array}$ \\
\hline $\begin{array}{l}\text { 'In the fumigation programme, open tussock country appeared in fair order, but any areas of cover- } \\
\text { matagouri, briar, gorse and broom-had large quantities of rabbit' (Leaning Rock Pest Destruction } \\
\text { Board minutes, } 24 \text { March 1970). }\end{array}$ \\
\hline $\begin{array}{l}\text { 'The rabbit which is in this type of country appears to live in gorse hedges and broom, which is } \\
\text { increasing very quickly. I do feel that we must do something in regards to the cover as I am sure it is } \\
\text { our major problem on flat country' (Blackstone Pest Destruction Board minutes, } 2 \text { February 1973). }\end{array}$ \\
\hline Gorse and thistles \\
\hline 'Riddle we \\
\hline 'Matthew cleaning up [i. e. weeding] round hedges in garden' (Kauru Hill diaries, 29 May 1873). \\
\hline 'McToben cleaning gorse seed \\
\hline Rabbits and thistles \\
\hline 'Cutting thistles and laying rabbit poison' (David Wallace diaries, 20 January 1906). \\
\hline e [rabbit eradicatio \\
\hline
\end{tabular}

Sources: The Kauru Hill diaries, held by the North Otago Museum and Archive, Oamaru; all other documentary sources are from the Hocken Collections, Uare Taoka o Hākena, University of Otago, Dunedin.

We traced more than three decades of such records (from 1874 to 1907) for Otematata Station in the Waitaki Valley and 40 years (from 1891 to 1930) for nearby Hakataramea Station. The former showed sheep numbers increasing from 25,000 in 1874 to 28,00011 years later (Figure 1). The first reference to rabbits was in 1885. Three years later the number of skins sent from the property had surged to 200,000. Sheep numbers declined while rabbit numbers remained high, but began to rise again in the late 1890s. There was a second surge in numbers of rabbits killed each year between 1893 and 1895, and a subsequent decline in sheep numbers. Rabbits on the station were evidently 
coming under control in the final three years of the nineteenth century, when their numbers declined to levels not seen since the mid-1880s, but later became more abundant. The situation in the first decade of the twentieth century was strikingly different from earlier years in that sheep numbers declined while numbers of rabbits killed were not historically large.

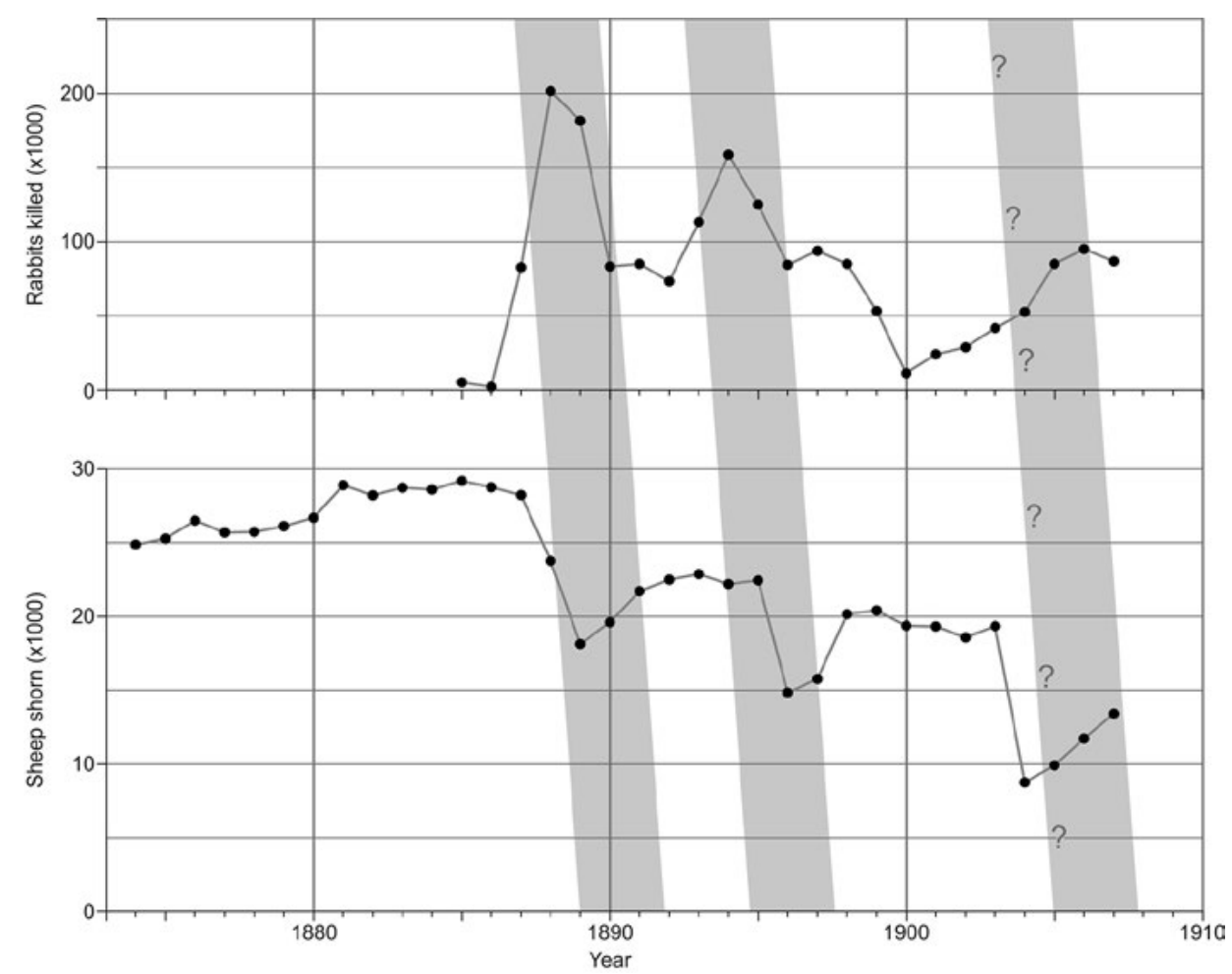

Figure 1: Numbers of rabbits killed (upper diagram) and sheep shorn (lower diagram) from 1874 to 1907 at Otematata Station in the Waitaki Valley. The three diagonal bands show the impact of spikes in rabbit density on flock size, and the question marks indicate uncertainty when increasing numbers of rabbits affected flock size.

Source: The authors' work, after NMA archive, Hocken Collections, Uare Taoka o Hākena, University of Otago, UN-028, Box 316).

The manager's records for Otematata Station include the annotation 'snow' against the 1904 tally of sheep shorn. The early years of the twentieth century were punctuated by adverse weather in Central Otago, the Mackenzie Country, and upper Waitaki Valley, as well as inland south and mid-Canterbury, but apparently not farther south. A report to the 1903 Annual General Meeting of the NMA in Edinburgh noted that 'a very serious snow storm took place in New Zealand on 17th July [1903] and from the advices we have received 
I fear that a considerable number of sheep on Hakataramea Station and a smaller number in Kawarau [Station, Central Otago] have succumbed' ${ }^{89}$ The Timaru Herald published several short articles about the adverse effects of winter snow-storms in inland south Canterbury, and on 11 July 1903 reported that the railway line from Timaru to Fairlie was blocked by snow-drifts. The link was not restored until 20 July. On 14 October 1904, the newspaper reported a major snowfall at Burke's Pass and in adjoining parts of south Canterbury that had 'disastrous effects on [new-born] lambs.' It is likely that adverse weather in winter and early spring led to widespread major stock losses and allowed rabbit numbers to increase until they could be brought back under control in the second half of the decade.

A similar analysis for Hakataramea Station showed the number of sheep shorn reached a peak in 1901 then declined, presumably in response to the reduced availability of nutritious forage on the property, but also to the manager's awareness of long-term carrying capacity and the need to reduce flock size. This decline continued until 1930, when records ceased (Figure 2). Missing records meant that we could not confirm the loss of sheep after heavy snowfalls, but we were able to collate annual expenditure on rabbit eradication and annual income from the sale of rabbit skins. Rabbit numbers on the property varied little between 1891 and the outbreak of the First World War, but by the end of hostilities Hakataramea Station had a serious rabbit problem, one that demanded major outlays on labour and materials. The sum spent on rabbit eradication between 1919 and $1926(£ 2,800)$, bracketing the period of intense activity, was greater than revenue from sale of the skins $(£ 2,000)$, implying that pest eradication, rather than a secondary income stream, was the goal. The graph of numbers of sheep shorn each year shows a small peak in 1894, a larger peak in 1901 and then a long decline. Sheep numbers on the station were at their lowest when rabbit numbers were at their highest.

89 NMA miscellaneous documents, 1903, Hocken Collections, Uare Taoka o Hākena, University of Otago, UN-028, Box 289. 


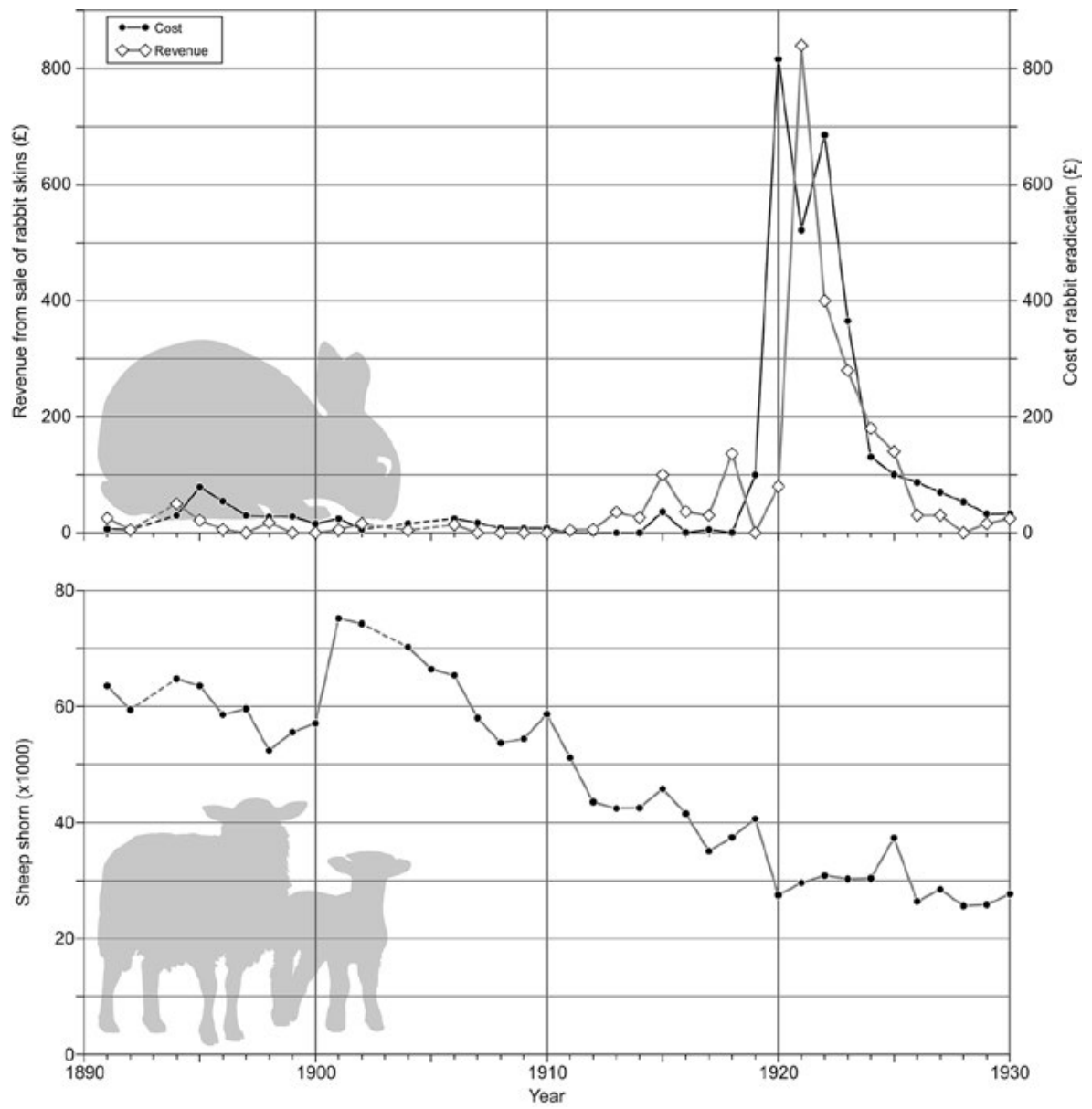

Figure 2: Cost of rabbit eradication and revenue from rabbit skins sold (upper diagram), and the number of sheep shorn (lower diagram) from 1891 to 1930 at Hakataramea Station in the Waitaki Valley.

Source: The authors' work, after NMA archive, Hocken Collections, Uare Taoka o Hākena, University of Otago, UN-028, Box 284.

\section{Five case studies}

The following words from a letter written on 21 April 1888 by the manager of the Invercargill branch of the NMA about a property at Seaward Downs, 10 kilometres south of Edendale in Southland in which the Company had a financial interest, ${ }^{90}$ point to links between cultivation, pasture management, infestations of weedy plants, rabbits, and uncontrolled gorse:

90 NMA miscellaneous documents, Hocken Collections, Uare Taoka o Hākena, University of Otago, UN-028, 
Everything had been most shamefully neglected, the fences being all in bad repair, the gorse overgrown and [fence] posts rotting ... Along the hedgerows rabbits are numerous but when the gorse is trimmed a few weeks trapping should get them well under [control], the fences at present being their chief station.

A great portion of the land appears to have been cropped two or three times and then left without sowing down, and now carries nothing but what has sprung up from the soil: [the grass, Yorkshire] fog and thistles chiefly, and this principally below the road where the land is very good, judging from the strong growth of the latter.

Five of our seven key sources ${ }^{91}$ contained sufficient information to enable us to estimate numbers of man-days per year expended on (a) burning tussock, clearing fern and shrubs, draining wetlands, and ploughing, (b) clipping broom and gorse hedges, disposing of the trash, and chipping self-sown plants from pastures and roadsides, (c) either chipping or digging up thistles, and (d) eradicating rabbits.
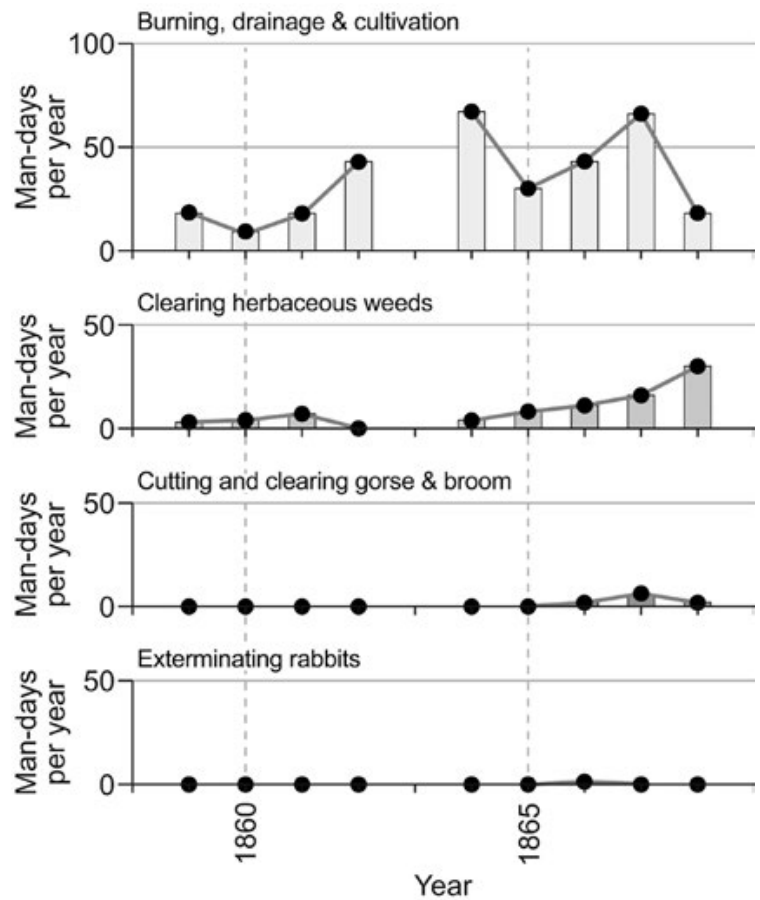

Figure 3: Man-days per annum spent on burning, cultivation, and drainage (upper diagram), chipping or digging up thistles (second diagram), and caring for domestic rabbits (bottom diagram) on Puketoi Station, Maniototo, Otago, from 1859 to 1868.

Source: The authors' work, after James Murison's diaries, Hocken Collections, Uare Taoka o Hākena, University of Otago, ARC-0612. 
Our earliest documentary records were from James Murison's station, Puketoi in Central Otago, where there could have been some cultivation before 1859 when Murison took over the lease, but from then until the station was sold a decade later the investment in human labour for land preparation and ploughing increased. In tandem, the effort to clear herbaceous weeds rose exponentially, with the most rapid increase after 1864 (Figure 3). Murison's only references to rabbits were to hutches for two domestic animals and their progeny. Twenty years later, this property in the Maniototo was one of the worst affected by rabbits, and remained so until the late twentieth century. In his diaries, Murison referred to broom hedges around the homestead in 1867 and 1868, but not to gorse.
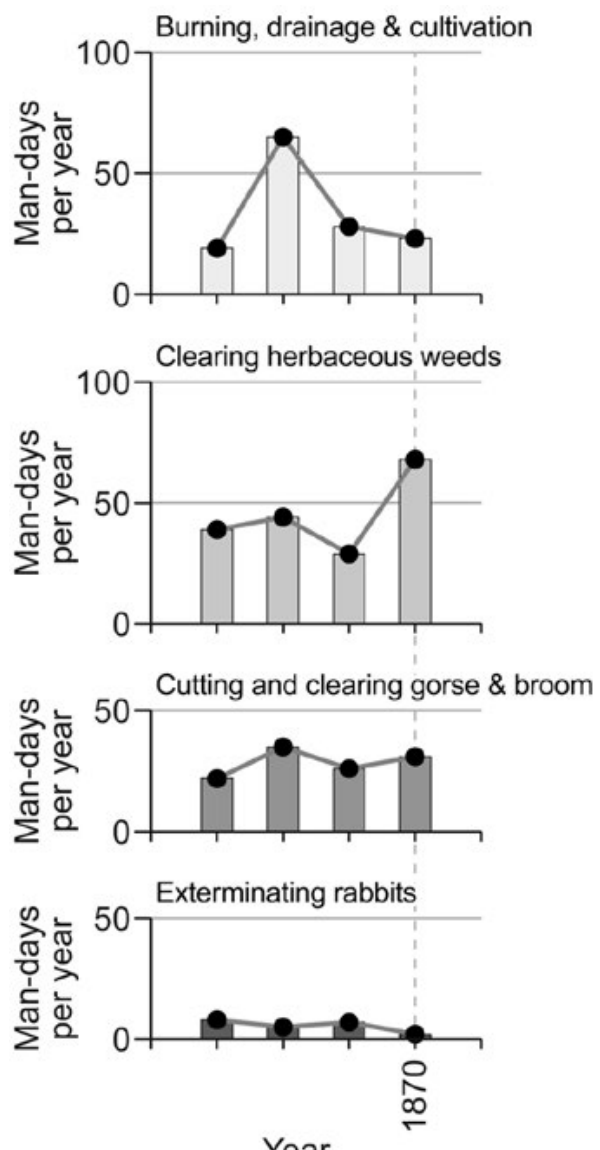

Year

Figure 4: Man-days per annum spent on burning, cultivation, and drainage (upper diagram), chipping or digging up thistles (second diagram), clipping mainly gorse hedges and chipping volunteer growth (third diagram), and hunting rabbits for sport and food (bottom diagram) on The Point Station, mid-Canterbury, from 1866 to 1870.

Source: The authors' work, after the Point Journal, Canterbury Museum and Archive, Christchurch. 
The second long run of documentary records was for The Point Station, located on the high plains and foothills of mid-Canterbury. It had been occupied for at least a decade before the Phillips family took up the lease in August 1866, but we did not find any record of cultivation before that date. By 1870, weeds were sufficiently common to require 60 man-days of labour in newly cleared and cultivated ground on a terrace of the Rakaia River, where the family grew oats to feed their draught and saddle horses, potatoes for residents and the domestic pigs, English grasses for hay, and wheat and barley for sale in Christchurch (Figure 4). From the outset, the Phillips family, their employees and contractors had established gorse and broom hedges, and by 1868 were investing more than 30 man-days annually clipping them after flowering as well as chipping self-sown plants from sown pastures and crop-land, and along the property boundaries. The main references to rabbits were to those shot during recreational hunting trips to the nearby bed of the Rakaia River. The bags were small, on some trips rabbits were not caught, and there were few references in the diaries to these animals occupying ground away from the river bed or eating garden, pasture and crop plants.

John Wither took over the lease of Sunnyside Station on the south shore of Lake Wakatipu in 1872. He then began an annual programme of burning and grubbing tussock, clearing small shrubs and clumps of bracken fern, draining depressions, and ploughing the lower terraces. He continued this regime until 1889, but from then until he handed over to his son in 1903 he reported generally less environmentally transformative work. His investment in labour to clear herbaceous weeds remained small until the early 1880 s, rose to a peak in 1887, and then declined to a long-term maintenance level. In 1898, the troughs evident in the three parts of this diagram were the consequence of heavy falls of snow and severe cold killing many of his sheep and forcing him to employ his financial resources to rebuild his flock. Rabbit eradication followed a similar pattern, although the peak was six years earlier (Figure 5). Rabbits evidently reached Sunnyside in 1875-76 but were uncommon until 1877-78, when the amount of labour required for eradication increased sharply. For a decade, labour input for pest eradication was often between 250 and 350 man-days per year, but declined after a second peak in 1890 as Wither, his employees, and contractors gained control over the pest. There was a third peak in 1900, and a rapid falling away thereafter. The station's broom, hawthorn, and gorse hedges required the normal maintenance, but Wither did not refer to self-sown plants of these three species. Figure 6 shows that extensive ploughing, burning, and wetland drainage created novel ecological opportunities for herbaceous weeds and rabbits, and as the pace of gross environmental disturbance declined, rabbits had access to progressively fewer niches and less manpower was needed to keep their numbers under control. 

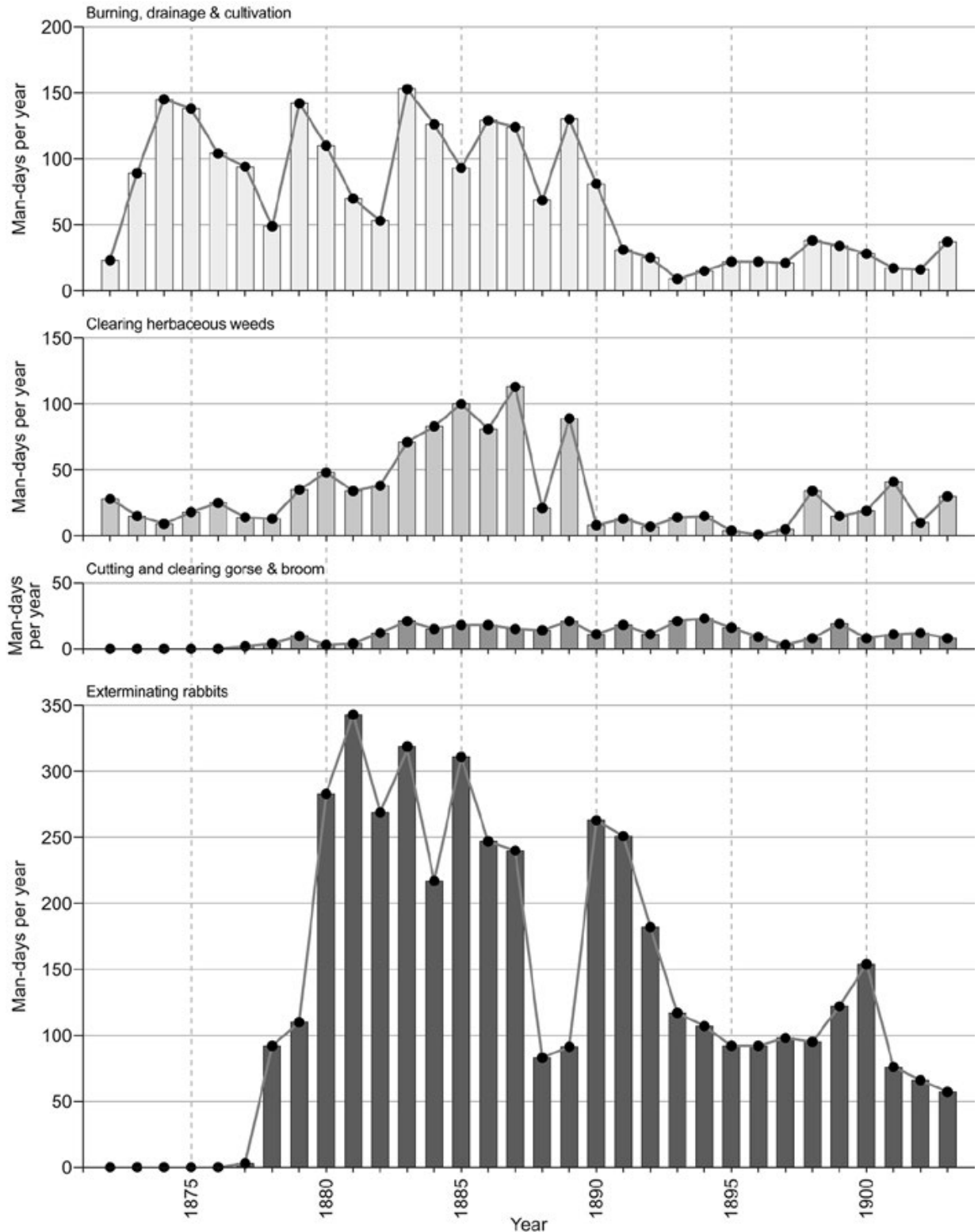

Figure 5: Man-days per annum spent on burning, cultivation, and drainage (upper diagram), chipping or digging up thistles (second diagram), clipping and clearing mostly gorse (third diagram), and exterminating rabbits (bottom diagram) on Sunnyside Station, Lake Wakatipu Basin, Otago, from 1872 to 1903.

Source: The authors' work, after James Wither's diaries, Hocken Collections, Uare Taoka o Hākena, University of Otago, 89-149. 

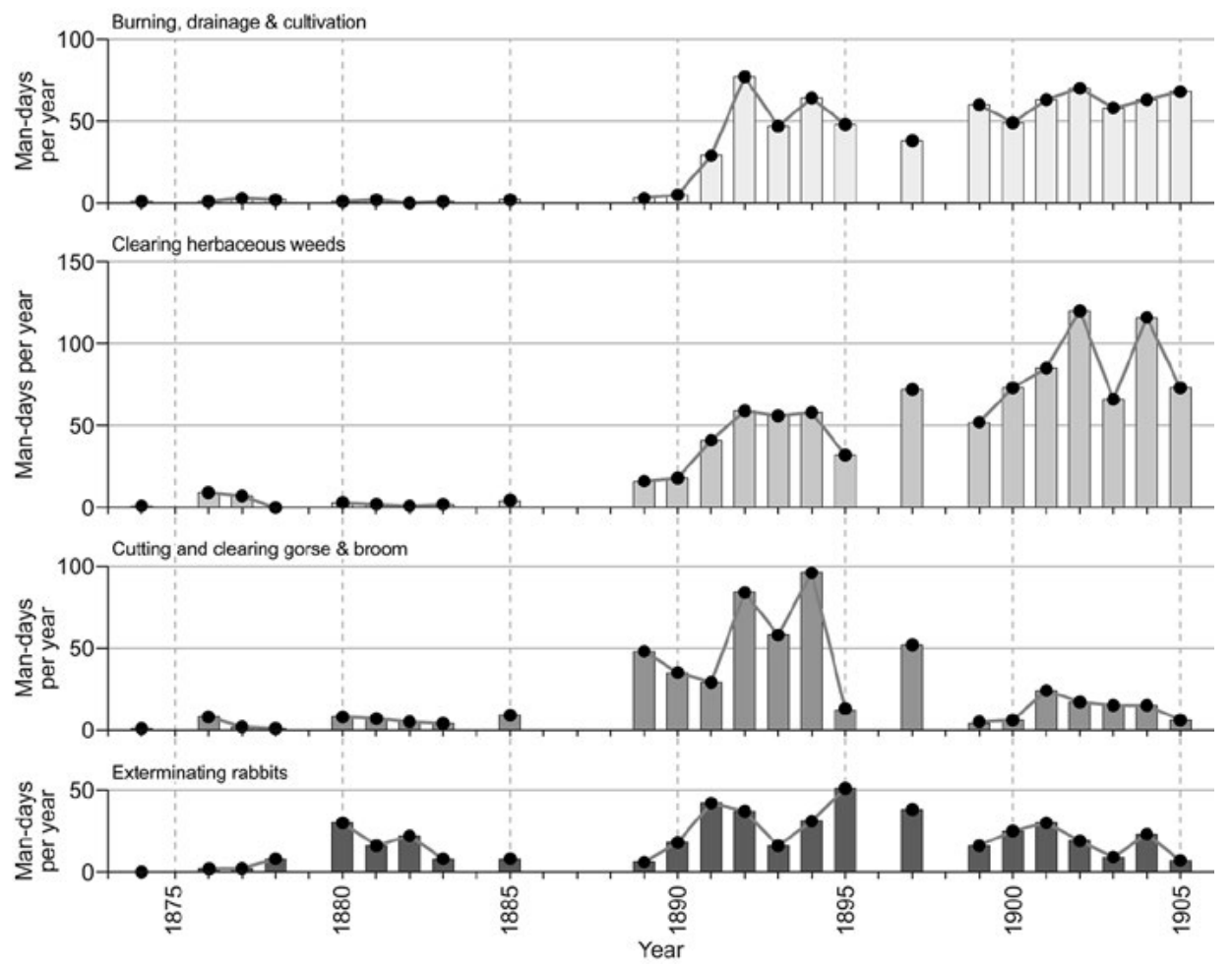

Figure 6: Man-days per annum spent on burning, cultivation, and drainage (upper diagram), chipping or digging up thistles (second diagram), clipping mostly gorse hedges and chipping volunteer growth (third diagram), and exterminating rabbits (bottom diagram) on the Davidson family farm near Waikaia in northern Southland from 1874 to 1905.

Source: The authors' work, after Joseph Davidson Senior and Junior diaries, Hocken Collections, Uare Taoka o Hākena, University of Otago, AG-523.

In the late 1870s, Joseph Davidson began to experience the first wave of rabbits moving northwards out of the Southland plains and into the low hill country along river valleys, formed tracks, and railway rights of way. Albeit with occasional recourse to professional rabbiters, he and his sons were able to keep the pest under control. The most rapid changes came after 1890, when he and his family increased the pace of tussock clearance on the low hill country and cultivated more terrace land beside the Waikaia River (Figure 6). Weed removal usually required more labour than did clearance and cultivation of tussock, shrub, and fern lands, or drainage of wetlands. There was a third surge in labour expended on rabbit extermination in 1885, then a slow decline to the end of the record in 1905. Significantly, Davidson had begun to target gorse and the much less common broom hedges as sites for rabbit extermination in the early 1890s, and after 1895 removed hedges and levelled sod walls. In the final decade of the 
documentary record, Davidson was regularly poisoning rabbits in his pastures, shooting them in river and stream valleys, poisoning them in the small area of modified tussock remaining in a hilly corner of his farm, and monitoring their spread from shrubby areas on neighbouring properties. His most persistent problem, and one that would remain until herbicides became available, was infestation of cultivated fields and hedgerows by Californian and Scotch thistles, sheep sorrel, vetch, and other herbaceous weeds.
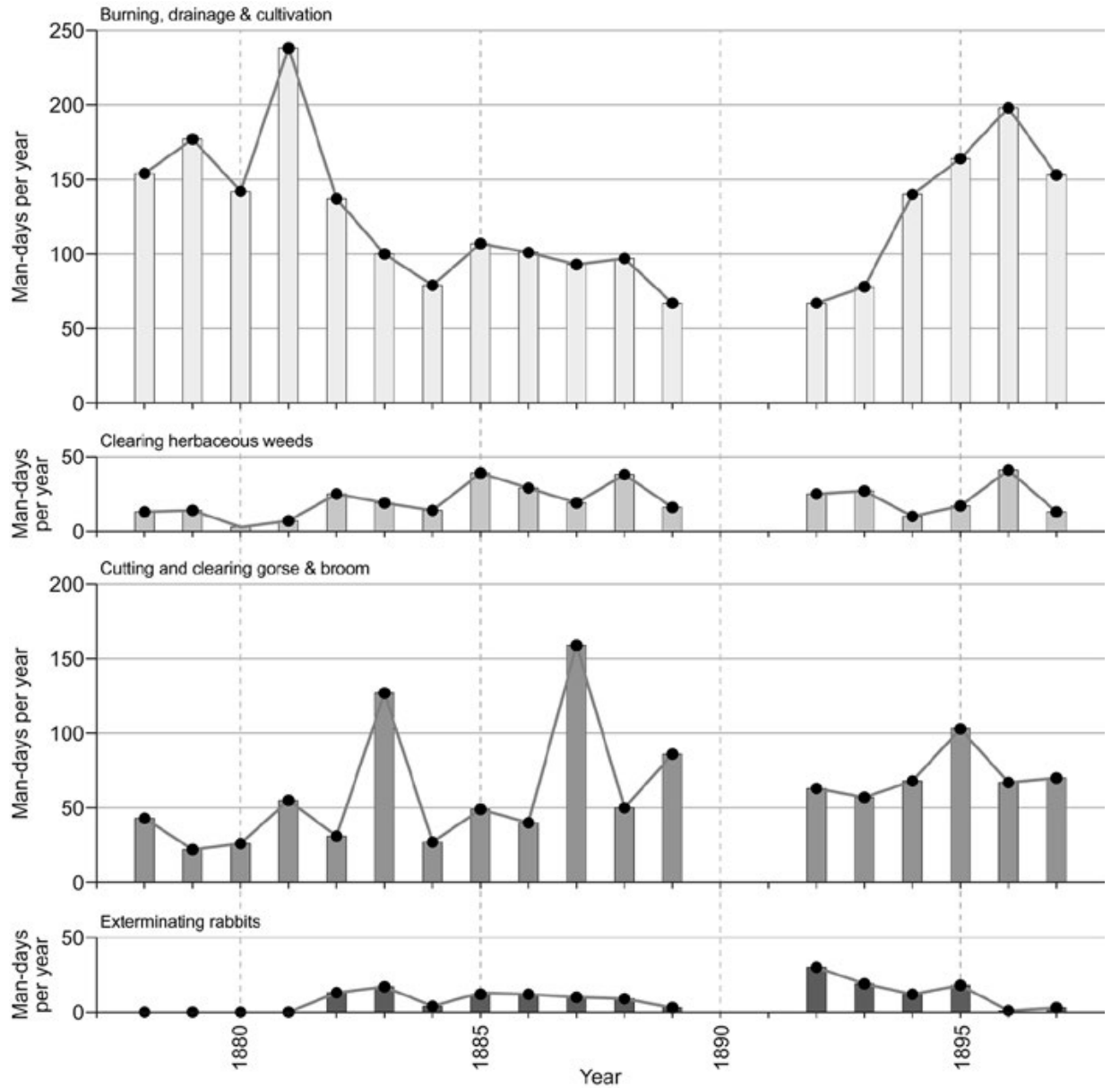

Figure 7: Man-days per annum spent on burning, cultivation, and drainage (upper diagram), chipping or digging up thistles (second diagram), clipping mostly gorse hedges and chipping volunteer growth (third diagram) and exterminating rabbits (bottom diagram) on the Wallace family farm, Clinton, Southland, from 1877 to 1897.

Source: The authors' work, after David Wallace's diaries, Hocken Collections, Uare Taoka o Hākena, University of Otago, MS-4031. 
The documentary record for David Wallace's farm near Clinton in eastern Southland showed a more complex situation. After an initial surge in cultivation and burning, there was a comparatively quiet decade before a second surge that lasted six years from 1892 (Figure 7). Rabbits were a persistent but not serious problem after 1885, and herbaceous weeds were kept under control by chipping and cultivation. Maintenance of gorse and broom hedges, and removal of volunteer plants, however, required costly outlays of human labour as hedges matured and self-sown plants became established in pastures.

Rabbits also caused economic hardship and environmental difficulties for James Preston on his sheep stations in Central Otago, the upper Waitaki Valley, and the Mackenzie Country, ${ }^{92}$ and he occasionally directed rabbiters to clear gorse from river beds and other preferred rabbit habitats on Haldon Station. ${ }^{93}$ Over a period of five years at Black Forest Station in the upper Waitaki Valley, two thirds of his annual financial outlay went to paying for exterminating rabbits. At the end of this period, Preston was unable to carry the financial burden and had to give up the lease.

In years when damp winters facilitated a dense sward of pasture grasses, intensive land use, property development, and livestock management weighed against the rabbit. ${ }^{94}$ Elsewhere in Otago, the rabbit inspector, J. A. Powell, had noted a decrease in rabbit numbers without eradication measures having been applied, and concluded that clearance of bracken, manuka, and noxious brushweed cover, coupled with increase in the area of improved pasture, had led to the drop in rabbit numbers. ${ }^{95}$

\section{The rise of gorse, rabbits, and thistles in southern New Zealand}

By the 1870s, settlers in the lowlands of southern New Zealand were experiencing the adverse effects of environmental disturbance; the Kauru Hill diaries from north Otago ${ }^{96}$ contain many references to Californian thistles springing up a few weeks after the first furrow had been ploughed to mark the line of a fence, hedge, or plantation. The seeds of thistles and other weedy plants reached

\footnotetext{
92 Holland, Home in the Howling Wilderness.

93 James Preston's diary, 26 May 1911, Hocken Collections, Uare Taoka o Hākena, University of Otago, MS-0989 / 277.

94 J. A. Powell's report to the Wakatipu Coordinating Committee, Agricultural Pests Destruction Council, Hocken Collections, 97-145.

95 J. A. Powell's report to the combined Wakatipu, mid-Wakatipu, Glenorchy, and Upper Shotover Pest Destruction Boards, in minutes of the Upper Shotover Pest Destruction Board, Hocken Collections, Uare Taoka o Hākena, University of Otago, 97-145.

96 Kauru Hill and Taipo Hill Station diaries, North Otago Museum, Oamaru.
} 
a property on the backs of sheep bought from neighbouring properties or at local sale-yards, as pollutants in sacks of pasture plant seeds and grain, and in soil on rooted trees and shrubs. They germinated and found a congenial habitat where the original vegetation cover had been fragmented, the litter layer destroyed, and the top soil exposed. In the final three decades of the nineteenth century, gorse, thistles, and rabbits made lightning progress through the grossly transformed environments of the open country, facilitated by widespread burning, ploughing, and drainage, development of a network of gravel roads, nation-wide extension of railways, and the sparsely vegetated gravel beds and banks of large and small rivers that drained from the uplands to the coast. Any experience that rural settlers might have had with these three organisms in the British Isles was scant preparation for what they would encounter in southern New Zealand.

Land holders learned how to shoot, trap, and poison rabbits, but until organic herbicides were commonly available they could only respond to outbreaks of weedy plants with axe, saw, shovel, and a box of matches, although on 3 March 1911 James Preston recorded in his diary that an unnamed resident of Haldon Station had 'put ground salt on thistles [to kill them]'. ${ }^{97}$ There was the added spur of stern penalties if they failed, which diverted expensive labour from property development to pest, plant, and animal control. Interestingly, although the first three generations of settlers learned much about pest animals and weeds, in their diaries we did not find a single acknowledgement that the problems they were experiencing could have been substantially of their own making.

When viewed through the lenses of ecological theory and human and nonhuman agency, it is evident that in the last three decades of the nineteenth and the first half of the twentieth century rural people in southern New Zealand were experiencing the adverse consequences of gross environmental disturbance, complicated by some of the most savage weather and severe flooding on record. Directly as well as indirectly, individual human agency led to the spread and establishment of weedy plants and pest animals on farms and stations, along strips of land set aside for road and rail links, in small settlements, and in river valleys. While land holders showed considerable resilience in the face of the threats posed by introduced plant and animal pest species to their livelihoods, communal agency spurred by legislation became essential in the 1880 s.

As agents, individual land holders were responsible for eradicating weedy plants and pest animals from their properties, observing the growth and behaviour of these newcomers in the partly transformed environments of their properties,

97 James Preston's diary, Hocken Collections, Uare Taoka o Hākena, University of Otago, MS-0989 / 277. 
and using that knowledge to manage adverse effects. They also consulted their neighbours about the timing and other details of control measures. When communal agency in the form of other land holders, iwi, or the state failed to keep rabbits under control, inspectors were hired by the state to check properties in rabbit-affected areas, advise land holders about control measures, set goals for eradication, and initiate legal action. Across southern New Zealand, the role of thistles and gorse as refuge for rabbits was known by the 1880s, but the sites where communal agency strove to bring them under control were public lands alongside roads and tracks, and in the beds and banks of rivers and streams. Even as the state was erecting regional rabbit-proof fences to restrict the spread of rabbits, individual land holders were putting up netting fences on vulnerable boundaries and within their properties to facilitate eradication of the pest and guard against re-invasion. In effect, individual and communal human agency operated in tandem from the 1880s onwards.

The experiences of land holders were shaped by new social and economic networks, as well as new plants and new animals. In the early years of organised settlement, the beneficial features of those economic, ecological, and human relationships allowed settlers to prosper, but their unanticipated consequences proved challenging in the long term because few land holders and commentators recognised the ecological nature of a farm or station. In the 1860s, James Hector had urged a scientific approach to agriculture and pastoral farming, and in a speech read to Dunedin members of the Young Men's Christian Association in 1862, he promoted the model in which every farm was a laboratory, every field an experiment, and every farmer a scientist: 'Exact observation is not merely idle curiosity but leads to very practical results. Gather facts from year to year, experiment if you can, and in time you will reap a harvest of profit. ${ }^{\prime 98}$

Hector had in mind carefully controlled experiments in which one factor at a time would be isolated and evaluated, but ecological thinking calls for a holistic approach. Things did not work out quite as Hector had advocated, and it took time for rural people and their advisors to learn how to evaluate and apply scientific principles to manage the new and ecologically untested ecosystems that settlers had created on their properties.

One early commentator, William Pember Reeves, regretted the loss of beauty as tracts of forest, tussock grass, shrub, and wetland gave way to farms and sheep stations across New Zealand:

98 The Otago Daily Times reported James Hector's lecture, 'The utility of natural science', in its 24 October 1862 issue. Hector, who was trained as medical doctor in Scotland, was appointed Director of the Geological Survey of Otago then Director of the Geological Survey and the Colonial Museum in Wellington. A productive scientist and talented administrator, he also served as Director of the Meteorological Department, the Colonial Observatory, the Wellington Time-ball Observatory, and the Wellington Botanic Garden. 
Bitter the thought:

is this the price we pay?

The price for progress;

beauty swept away. ${ }^{99}$

What Reeves deplored was the consequence of an unmanaged shift from an evolutionarily tested ecology to one where the desired end-point was virtually hijacked by plant and animal interlopers from the Northern Hemisphere doing what their genes had equipped them for. This is a long-standing theme in the environmental history of New Zealand, and the books by Thomas Potts, Herbert Guthrie-Smith, Andrew Clark, and Alfred Crosby chart the progress of the nation's thinking about its rural landscapes. ${ }^{100}$

It is now too late to turn back the tide of environmental transformation, but there is a growing understanding amongst rural people of the desirable features of a landscape in which sizeable remnants of once widespread ecosystems can coexist with agro-systems in a functional, economically productive, harmonious, aesthetically pleasing, and distinctive whole. Would the first generation of European settlers in southern New Zealand have done things differently if the core notions of scientific ecology had been formulated and disseminated in the second half of the nineteenth century? We may also ask what might have happened if the first generation of European settlers had developed their rural properties at a slower pace, respecting lessons that they and their neighbours had learned during their time on the land? An observant settler might have learnt enough in a decade of close observation to make reasonably reliable weather forecasts, but it would have taken a lifetime of dedicated observation and experimentation to comprehend its ecology. ${ }^{101}$

\section{Acknowledgements}

We acknowledge invaluable assistance from the staff of the Hocken Collections, Uare Taoka o Hākena, University of Otago, including permission to quote from manuscript sources and reproduce historic photographs. The Chief Archivist of the Canterbury Museum helped us gain permission to quote from The Point

99 William Pember Reeves, New Zealand, and Other Poems (London: Grant Richards, 1898). Several decades later Herbert Guthrie-Smith sounded a more optimistic note when he wrote: 'The lamentable laissez-faire in regard to misuse of the land and water is passing away. For the first time in the history of the globe we are about to cease to maltreat this kindly old world of ours' (Tutira, 3rd ed., 422).

100 Thomas Potts, Out in the Open: A Budget of Scraps of Natural History, Gathered in New Zealand (Christchurch: Capper Press, 1976. 1st ed. 1882); Guthrie-Smith, Tutira; Andrew Clark, The Invasion of New Zealand by People, Plants and Animals: The South Island (New Brunswick, NJ: Rutgers University Press, 1949); Crosby, Ecological Imperialism.

101 Guthrie-Smith, Tutira. 
Journal. The former Hocken Librarian, Stuart Strachan, directed us to the riches of the National Mortgage \& Agency Company archive held by the Hocken Collections, and the Archivist at Fletcher Challenge kindly granted permission for us to read and quote information from that material. Ossie Brown told us about current practice in rabbit extermination in Central Otago. Frank Leckie directed us to much useful manuscript and published material, and Dr George Davis advised us about government reports. The referees and the editor helped us clarify the argument. The diagrams were drafted by Tim Nolan, Black Ant Mapping Solutions, Christchurch, and Peter Holland acknowledges the generous provision of workspace and facilities by the Department of Geography, University of Otago. 
This text is taken from International Review of Environmental History, Volume 1, 2015, edited by James Beattie, published 2015 by ANU Press, The Australian National University, Canberra, Australia. 